\title{
Measurement of Intracellular Free Zinc in Living Cortical Neurons: Routes of Entry
}

\author{
Stefano L. Sensi, Lorella M. T. Canzoniero, Shan Ping Yu, Howard S. Ying, Jae-Young Koh, \\ Geoffrey A. Kerchner, and Dennis W. Choi \\ Center for the Study of Nervous System Injury and Department of Neurology, Washington University School of Medicine, \\ St. Louis, Missouri 63110
}

\begin{abstract}
We used the ratioable fluorescent dye mag-fura-5 to measure intracellular free $\mathrm{Zn}^{2+}\left(\left[\mathrm{Zn}^{2+}\right]_{\mathrm{i}}\right)$ in cultured neocortical neurons exposed to neurotoxic concentrations of $\mathrm{Zn}^{2+}$ in concert with depolarization or glutamate receptor activation and identified four routes of $\mathrm{Zn}^{2+}$ entry. Neurons exposed to extracellular $\mathrm{Zn}^{2+}$ plus high $\mathrm{K}^{+}$responded with a peak cell body signal corresponding to $a\left[\mathrm{Zn}^{2+}\right]_{i}$ of $35-45 \mathrm{~nm}$. This increase in $\left[\mathrm{Zn}^{2+}\right]$ was attenuated by concurrent addition of $\mathrm{Gd}^{3+}$, verapamil, $\omega$-conotoxin GVIA, or nimodipine, consistent with $\mathrm{Zn}^{2+}$ entry through voltage-gated $\mathrm{Ca}^{2+}$ channels. Furthermore, under conditions favoring reverse operation of the $\mathrm{Na}^{+}-\mathrm{Ca}^{2+}$ exchanger, $\mathrm{Zn}^{2+}$ application induced a slow increase in $\left[\mathrm{Zn}^{2+}\right]_{i}$ and outward whole-cell current sensitive to benzamil-amiloride. Thus, a second route of $\mathrm{Zn}^{2+}$ entry into neurons may be via
\end{abstract}

transporter-mediated exchange with intracellular $\mathrm{Na}^{+}$. Both NMDA and kainate also induced rapid increases in neuronal $\left[\mathrm{Zn}^{2+}\right]_{\mathrm{i}}$. The NMDA-induced increase was only partly sensitive to $\mathrm{Gd}^{3+}$ or to removal of extracellular $\mathrm{Na}^{+}$, consistent with a third route of entry directly through NMDA receptor-gated channels. The kainate-induced increase was highly sensitive to $\mathrm{Gd}^{3+}$ or $\mathrm{Na}^{+}$removal in most neurons but insensitive in a minority subpopulation ("cobalt-positive cells"), suggesting that a fourth route of neuronal $\mathrm{Zn}^{2+}$ entry is through the $\mathrm{Ca}^{2+}$ permeable channels gated by certain subtypes of AMPA or kainate receptors.

Key words: mag-fura-5; voltage-gated calcium channels; sodium-calcium exchanger; calcium; sodium; glutamate; AMPA; NMDA; neurotoxicity; global ischemia; hypoxia
Zinc is required by all cells, playing a critical role in the control of gene transcription and metalloenzyme function (Vallee and Falchuk, 1993; Berg and Shi, 1996). In addition, $\mathrm{Zn}^{2+}$ likely serves as a mediator of cell-cell signaling in the CNS (Frederickson, 1989; Frederickson and Moncrieff, 1994). The mammalian brain contains a high concentration of histochemically reactive $\mathrm{Zn}^{2+}$, primarily localized to glutamatergic terminals (Danscher, 1984; Perez-Clausell and Danscher, 1985) and released with neuronal activity (Howell et al., 1984). Endogenously released $\mathrm{Zn}^{2+}$ may reach $100 \mu \mathrm{M}$ concentrations in the extracellular space (Assaf and Chung, 1984) and alter the behavior of multiple channels and receptors (Harrison and Gibbons 1994; Smart et al., 1994), in particular inhibiting NMDA receptors (Peters et al., 1987; Westbrook and Mayer, 1987; Christine and Choi, 1990).

Furthermore, intense exposure to $\mathrm{Zn}^{2+}$ can be neurotoxic, killing cortical neurons after several minutes (Yokoyama et al., 1986). This neurotoxicity appears also to be mediated by $\mathrm{Zn}^{2+}$ influx, in large part through voltage-gated $\mathrm{Ca}^{2+}$ channels and also through NMDA receptor-gated channels (Koh and Choi, 1994) and $\mathrm{Ca}^{2+}$-permeable AMPA/kainate receptor-gated channels (Yin and Weiss, 1995). Pathophysiological relevance has been suggested by observations that brain $\mathrm{Zn}^{2+}$ translocates from presynaptic terminals into the postsynaptic cell bodies of neurons

Received May 15, 1997; revised Sept. 26, 1997; accepted Sept. 30, 1997.

This work was supported by National Institutes of Health Grant NS 30337 (D.W.C.). G.A.K. is an H. Hughes Medical Student Research Training Fellow. We thank D. Turetsky for assistance with the 293 cell line and Dr. K. Hyrc, Dr. M. Grabb, Dr. D. Lobner, and Dr. L. L. Dugan for helpful discussions.

S.L.S. and L.M.T C. contributed equally to this report.

Correspondence should be addressed to Dr. Dennis W. Choi, Department of Neurology, Box 8111, 660 South Euclid, St. Louis, MO 63110.

Copyright (c) 1997 Society for Neuroscience $0270-6474 / 97 / 179554-11 \$ 05.00 / 0$ dying after prolonged seizures (Sloviter, 1985; Fredrickson et al., 1989) or transient global ischemia (Tonder et al., 1990; Koh et al., 1996), together with the finding that intraventricular administration of Ca-EDTA can attenuate global ischemia-induced neuronal death (Koh et al., 1996).

Although it would be useful to understand how neurons regulate intracellular cytosolic free $\mathrm{Zn}^{2+}$ concentrations $\left(\left[\mathrm{Zn}^{2+}\right]_{\mathrm{i}}\right)$, at present, the tools available for measuring dynamic changes in $\left[\mathrm{Zn}^{2+}\right]_{\mathrm{i}}$ are limited. The $\mathrm{Zn}^{2+}$-selective fluorescent dye 6methoxy-8- $p$-toluene sulfonamide quinoline (TSQ) has provided valuable qualitative information about the location of chelatable $\mathrm{Zn}^{2+}$ in cells and tissues (Frederickson et al., 1987; Weiss et al., 1993), but limitations of solubility as well as possible complex interactions with membrane-bound $\mathrm{Zn}^{2+}$ have precluded quantitative measurement of $\left[\mathrm{Zn}^{2+}\right]_{\mathrm{i}}$ (Andrews et al., 1995). Recently, other sulfonamide derivatives of quinoline have been developed: (1) TFLZn, which has been used to detect $\left[\mathrm{Zn}^{2+}\right]$ in synaptic terminals in hippocampal slices (Budde et al., 1997), in which high levels of $\mathrm{Zn}^{2+}$ are present (Frederickson, 1989); and (2) zinquin, which has been used to detect $\left[\mathrm{Zn}^{2+}\right]_{\mathrm{i}}$ in thymocytes, pancreatic islet cells, and hepatocytes (Zalewski et al., 1993, 1994; Brand and Kleineke, 1996). However, significant limitations are posed by the low affinity of these indicators for $\mathrm{Zn}^{2+}$ and, at least in the case of zinquin, by uneven intracellular distribution, perhaps reflecting sequestration. Other recently identified candidate $\mathrm{Zn}^{2+}$ indicators, Newport green and APTRA-BTC (Haugland, 1996), have promising specificity but low affinity.

Another approach to measuring $\left[\mathrm{Zn}^{2+}\right]_{\mathrm{i}}$ is to use fura-2-based, $\mathrm{Ca}^{2+}$-sensitive ratioable fluorescent dyes. Fura- 2 binds transition metals such as $\mathrm{Zn}^{2+}$ with much higher affinity than $\mathrm{Ca}^{2+}$, producing a similar shift in emitted fluorescence (Grynkiewicz et al., 
1985; Simons, 1993). Fura-2 itself has been used to monitor $\left[\mathrm{Zn}^{2+}\right]_{\mathrm{i}}$ in chromaffin cells (Vega et al., 1994), in myocytes and transfected cell lines (Atar et al., 1995), in bovine liver cells (Hechtenberg and Beyersmann, 1993), and in synaptosomes (Denny and Atchison, 1994), although confounding interference from changes in $\left[\mathrm{Ca}^{2+}\right]_{\mathrm{i}}$ is difficult to exclude.

In the present study, we explored the use of the related dye mag-fura-5 for real-time measurements of $\left[\mathrm{Zn}^{2+}\right]_{i}$ in living cortical neurons. Simons (1993) reported that a similar analog, magfura-2, could be used to measure $\mathrm{Zn}^{2+}$ in solution over the 1-100 nM range, even in the presence of moderate $\mathrm{Ca}^{2+}$, reflecting the higher affinity of the dye for $\mathrm{Zn}^{2+}\left(K_{\mathrm{d}}=20 \mathrm{nM}\right)$ over $\mathrm{Ca}^{2+}$ or $\mathrm{Mg}^{2+}$. We selected mag-fura-5 over mag-fura- 2 because the former has additionally reduced affinity for $\mathrm{Ca}^{2+}$ or $\mathrm{Mg}^{2+}$ compared with mag-fura-2 (Haugland, 1996).

\section{MATERIALS AND METHODS}

Cell culture. Mixed cultures were prepared as described previously (Rose et al., 1993). Briefly, dissociated neocortices from embryo mice at 15-16 d gestation were plated in glass bottom $35 \mathrm{~mm}$ dishes (MatTek, Ashland, MA) at a density of three hemispheres $/ 10 \mathrm{ml}$ of plating medium containing 5\% fetal bovine serum and 5\% horse serum. Cultures were fed once a week with growth medium (5\% horse serum). Videomicroscopy experiments were performed at $12-17 \mathrm{~d}$ in vitro.

$\left[\mathrm{Zn}^{2+}\right]_{i}$ measurement. To monitor $\left[\mathrm{Zn}^{2+}\right]_{\mathrm{i}}$, cells were loaded with magfura- 5 by incubation with mag-fura- $5 \mathrm{AM}$ at the concentration of $3 \mu \mathrm{M}$ for $10 \mathrm{~min}$ in a HEPES-buffered solution containing (in $\mathrm{mM}$ ): $\mathrm{NaCl} 120, \mathrm{KCl}$ 5.4, $\mathrm{MgCl}_{2}$ 0.8, HEPES 20, glucose 15, $\mathrm{CaCl}_{2} 1.8$, and $\mathrm{NaOH} 10, \mathrm{pH} 7.4$, at room temperature. Cells were washed and incubated for an additional 20 min in the HEPES-buffered solution. After loading, neurons were washed twice with the same solution, but lacking $\mathrm{Mg}^{2+}$ and $\mathrm{Ca}^{2+}$. $\mathrm{Na}^{+}$-free solutions were made by substituting $\mathrm{NaCl}$ and $\mathrm{NaOH}$ with equimolar amounts of $\mathrm{N}$-methyl-D-glucamine (NMDG) and adjusting the $\mathrm{pH}$ to 7.4 with $\mathrm{HCl}$.

All experiments were performed at room temperature under constant perfusion $(2 \mathrm{ml} / \mathrm{min})$ on the stage of a Nikon Diaphot inverted microscope equipped with a $75 \mathrm{~W}$ Xenon lamp and a Nikon $40 \times, 1.3$ numerical aperture, epifluorescence oil immersion objective. Light was passed through 340 and $380 \mathrm{~nm}$ excitation filters mounted on a filter wheel with a computer-controlled filter driver. To avoid photobleaching of the cells under observation, the fluorescence intensity was attenuated with neutral density filters. The light was then reflected off a dichroic mirror $(450 \mathrm{~nm})$ and passed through a $510 \mathrm{~nm}$ emission filter.

Images were acquired with an intensified CCD camera (Quantex) and digitized using a Metafluor 2.5 software (Universal Imaging, West Chester, PA). Background fluorescence was subtracted from both (340 and $380 \mathrm{~nm}$ ) images at the beginning of each experiment.

To determine the $K_{\mathrm{d}}$ of mag-fura- 5 for $\mathrm{Zn}^{2+}$, we recorded excitation spectra of mag-fura-5 free acid $(1 \mu \mathrm{M})$ solution containing (in $\mathrm{mM}$ ): $\mathrm{KCl}$ 100, EGTA 0.1, and 4-morphoinepropanesulfonic acid 10, $\mathrm{pH} \mathrm{7,} \mathrm{in} \mathrm{a}$ spectrofluorimeter (LS 50; Perkin-Elmer, Norwalk, CT) at room temperature. Various $\mathrm{ZnCl}_{2}$ concentrations (from 0 to $0.2 \mathrm{mM}$ ) were added to the calibrating solution via a micrometer syringe (Hamilton, Reno, NV).

To calculate free $\mathrm{Zn}^{2+}$ concentration, we used Microsoft Excel (Solver) and the following equation: $\left[\mathrm{Zn}^{2+}\right]=K_{\mathrm{d}}[\mathrm{ZnEGTA}] /[$ EGTA], where a dissociation constant $\left(K_{\mathrm{d}}\right)$ of EGTA for $\mathrm{Zn}^{2+}$ of $7.09 \mathrm{nM}$ at $\mathrm{pH} 7$ was taken and modified by $0.02 \mathrm{log}$ unit per 0.01 increase in $\mathrm{pH}$ (Grynkiewiecz et al., 1985). $K_{\mathrm{d}}$ of mag-fura- 5 for $\mathrm{Zn}^{2+}$ was obtained by plotting the $\log \left[\left(F-F_{\min }\right) /\left(F_{\max }-F\right)\right]$ versus the log of free $\left[\mathrm{Zn}^{2+}\right]$ (Grynkiewicz et al., 1985), where $F, F_{\min }$, and $F_{\max }$ are the fluorescence intensity values obtained with an excitation of $380 \mathrm{~nm}$ at each $\left[\mathrm{Zn}^{2+}\right]$, at $\left[\mathrm{Zn}^{2+}\right]$ $=0$, and at saturating $\left[\mathrm{Zn}^{2+}\right]$, respectively. This plot gives an $x$-intercept of 7.56, so $K_{\mathrm{d}}=27 \mathrm{nM}$ (Fig. 1 ).

This $K_{\mathrm{d}}$ value of $27 \mathrm{nM}$ was used in the ratio formula: $\left[\mathrm{Zn}^{2+}\right]=$ $K_{\mathrm{d}} \cdot S_{\mathrm{f} 2} / S_{\mathrm{b} 2} \cdot\left[\left(R-R_{\min }\right) /\left(R_{\max }-R\right)\right]$, where $R$ is the observed $340 / 380$ fluorescence ratio (Grynkiewicz et al., 1985), $R_{\min }$ is the $340 / 380$ fluorescence ratio value determined in mag-fura-5-loaded cortical neurons exposed to $0 \mathrm{Zn}^{2+}$ and $100 \mu \mathrm{M} N, N^{\prime}, N^{\prime}$-tetrakis (2-pyridylmethyl) ethylenediamine (TPEN), and $R_{\max }$ is $340 / 380$ fluorescence ratio value determined in mag-fura-5-loaded cortical neurons exposed to $20 \mu \mathrm{M}$ of the selective $\mathrm{Zn}^{2+}$ ionophore $\mathrm{Na}^{+}$-pyrithione in the presence of $1 \mathrm{~mm}$

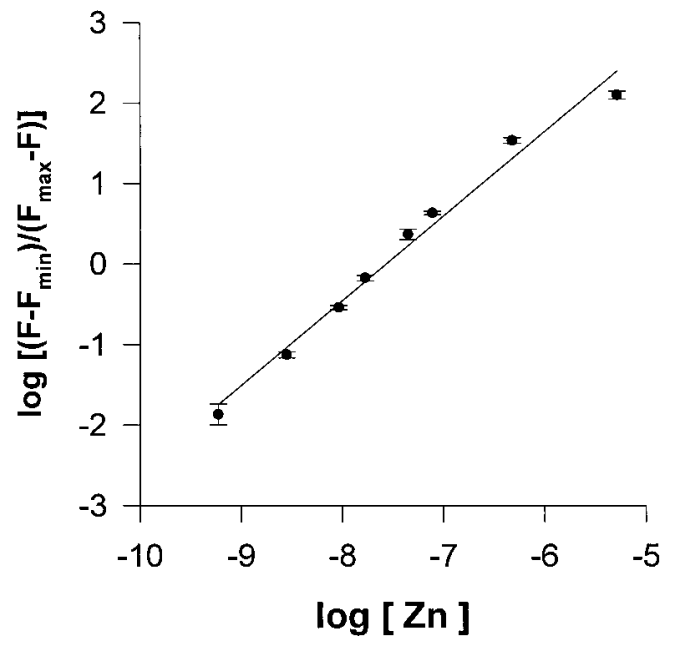

Figure 1. $K_{\mathrm{d}}$ of mag-fura-5 for $\mathrm{Zn}^{2+}$. Hill plot analysis derived from plotting the $\log \left[\left(F-F_{\min }\right) /\left(F_{\max }-F\right)\right]$ versus the log of free $\left[\mathrm{Zn}^{2+}\right]$. Values were obtained by using a mag-fura-5-free acid solution at various $\left[\mathrm{Zn}^{2+}\right]$, as described in Materials and Methods. Each point represents the mean \pm SEM from four different experiments.

$\mathrm{Zn}^{2+} . S_{\mathrm{f} 2}$ indicates the fluorescence intensity at 380 at $R_{\min } ; S_{\mathrm{b} 2}$ indicates the fluorescence intensity at 380 at $R_{\max }$.

Zinquin-ethyl ester (excitation, $380 \mathrm{~nm}$; emission, $510 \mathrm{~nm}$ ), APTRABTC (excitation, 380/440; emission, $510 \mathrm{~nm}$ ), and Newport green diacetate (excitation, $495 \mathrm{~nm}$; emission, $530 \mathrm{~nm}$ ) were tested by using the same microscope setting equipped with the appropriate set of filters.

Whole-cell recording of $\mathrm{Na}^{+}-\mathrm{Ca}^{2+}$ exchanger current. A $35 \mathrm{~mm}$ culture dish was used as a recording chamber on the stage of an inverted microscope (Nikon). Neurons of 15-20 $\mu \mathrm{m}$ diameter, with phase-bright cell bodies, were chosen for recordings. Neuronal identity has been confirmed previously by Nissl staining and electrophysiological characterization (Choi et al., 1987). Patch electrodes had a tip resistance of 10-15 M $\Omega$ (fire-polished). Voltage clamp was achieved by using an EPC-7 amplifier (List Electronic, Darmstadt, Germany). Series resistance compensation and capacitance compensation were routinely applied. Whole-cell current was sampled digitally at $500 \mu \mathrm{sec}$. The current signals were filtered by a $3 \mathrm{kHz}$, three-pole Bessel filter. Current traces were displayed and stored on a Macintosh computer (Quatra 950; Apple, Santa Clara Valley, CA) using the data acquisition and analysis program PULSE (HEKA Electronik, Pfalz, Germany). To test $\mathrm{Zn}^{2+}$-activated membrane current, solutions were delivered to the selected neuron body via pressure ejection from a delivery pipette of $100 \mu \mathrm{m}$ internal diameter placed $\sim 100 \mu \mathrm{m}$ from the cell body, using the DAD-12 superfusion system (Adams \& List, Westbury, NY). The extracellular solution contained (in mM): NMDG 120, HEPES 10 , and D-glucose 10 , with or without $\mathrm{ZnCl}_{2}$ 1. The pipette solution contained (in $\mathrm{mm}$ ): $\mathrm{NaCl} 60$, Cs-acetate $70, \mathrm{CaCl}_{2} 4.2, \mathrm{Mg}_{2}$-ATP 2, BAPTA 10, and HEPES 10. In addition, TTX $(0.5 \mu \mathrm{M})$, TEA $(5 \mathrm{mM})$, nifedipine $(10 \mu \mathrm{M})$, and ouabain $(20 \mu \mathrm{M})$ were included regularly in extracellular solutions to block $\mathrm{Na}^{+}$ channels, $\mathrm{K}^{+}$channels, dihydropyridine-sensitive $\mathrm{Ca}^{2+}$ channels, and $\mathrm{Na}^{+} / \mathrm{K}^{+}$ATPase, respectively. Solution $\mathrm{pH}$ was adjusted to 7.3 by adding $\mathrm{HCl}$ or $\mathrm{NaOH}$ as needed. Neuronal input resistance was measured at -70 and $-10 \mathrm{mV}$, using an external solution containing (in $\mathrm{mM}$ ): $\mathrm{NaCl} 124, \mathrm{KCl} 5$, TTX 0.002 , HEPES 20, and glucose 15 , with or without $\mathrm{MgCl}_{2} 0.8$ and $\mathrm{CaCl}_{2}$ 2; and an internal solution containing (in $\mathrm{mM}$ ): $\mathrm{KCl}$ $140, \mathrm{MgCl}_{2} 2$, HEPES 10, and BAPTA 0.3 .

Cobalt staining. After $\mathrm{Zn}^{2+}$-imaging experiments, $\mathrm{Co}^{2+}$ uptake was performed as described previously (Turetsky et al., 1994). Cells were exposed to $100 \mu \mathrm{M}$ kainate plus $5 \mathrm{mM} \mathrm{CoCl}_{2}$ in uptake buffer containing (in mM): sucrose 139, $\mathrm{NaCl} 57.5, \mathrm{KCl} 5, \mathrm{MgCl}_{2} 2, \mathrm{CaCl}_{2} 1$, glucose 12, and HEPES 10, pH 7.6, for $30 \mathrm{~min}$ at room temperature. Cultures were then washed with uptake buffer plus $3 \mathrm{~mm}$ EDTA to remove extracellular $\mathrm{Co}^{2+}$ and incubated in $0.12 \%\left(\mathrm{NH}_{4}\right)_{2} \mathrm{~S}$ for $5 \mathrm{~min}$ to precipitate intracellular $\mathrm{Co}^{2+}$. After three washes in uptake buffer, cells were fixed in $4 \%$ paraformaldehyde for $30 \mathrm{~min}$. For silver enhancement, cultures were washed three times in development buffer (in mM: sucrose 292, hydroquinone 15.5, and citric acid 42) and incubated in $0.1 \% \mathrm{AgNO}_{3}$ in 


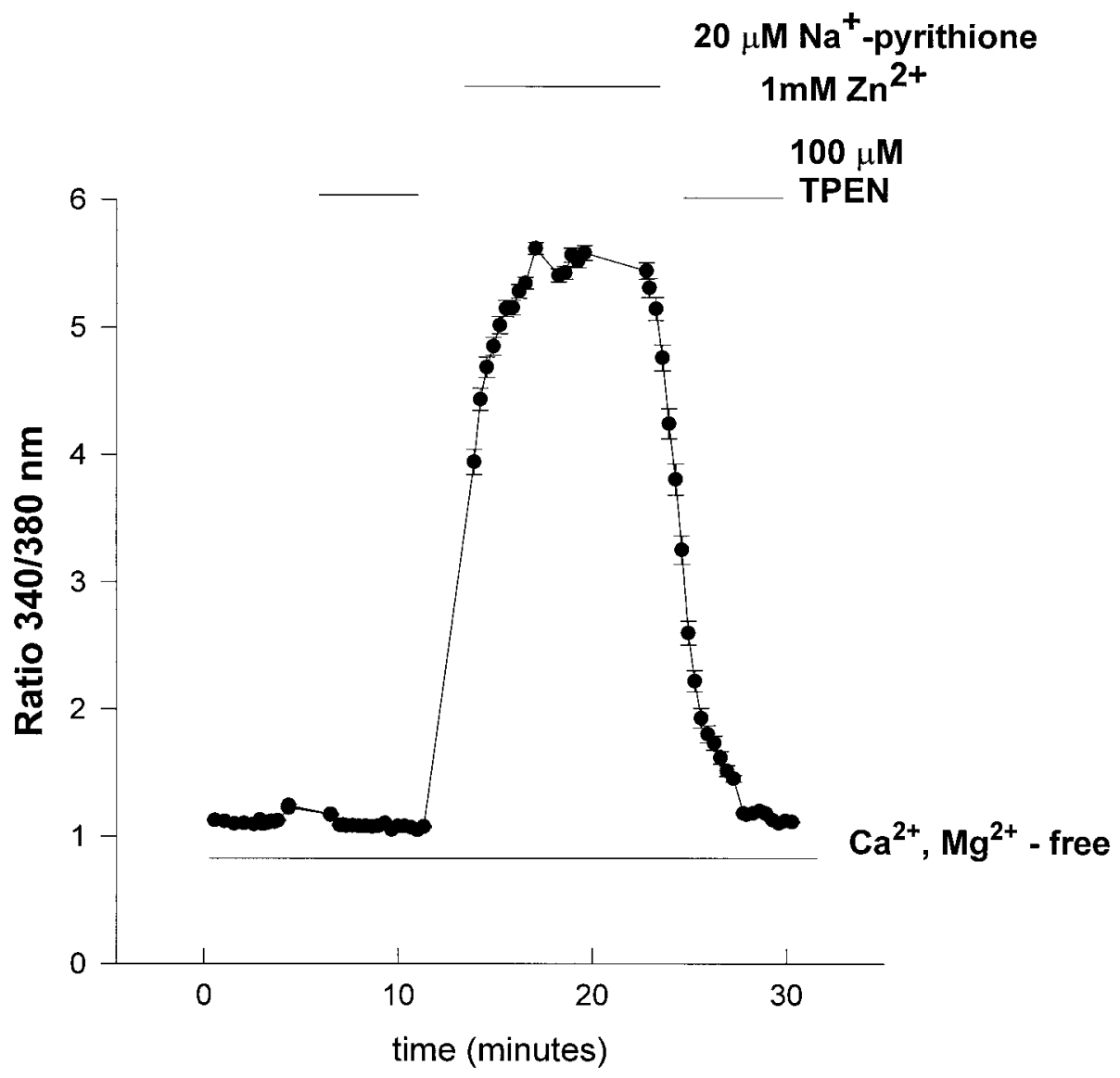

Figure 2. Calibration of mag-fura-5 detection of $\left[\mathrm{Zn}^{2+}\right]_{\mathrm{i}}$ in cortical neurons. Cortical neurons were loaded with mag-fura- 5 and bathed in medium lacking $\mathrm{Ca}^{2+}$ or $\mathrm{Mg}^{2+}$. At the indicated times, $20 \mu \mathrm{M} \mathrm{Na}^{+}$-pyrithione plus $1 \mathrm{mM} \mathrm{Zn}^{2+}$ or $100 \mu \mathrm{M}$ TPEN were added by bath perfusion, and the $340 / 380 \mathrm{~nm}$ fluorescence ratio was determined (mean \pm SEM, $n=24$ cells). Experiment is representative of three. development buffer at $50^{\circ} \mathrm{C}$ on a slide warmer. This solution was changed at 15 min intervals, and enhancement was monitored periodically by microscopic observation. When enhancement was complete (usually after $45-50 \mathrm{~min}$ ), the reaction was terminated by washing three times in warm development buffer. Once stained, fields were relocated by an independent observer lacking knowledge of the fluorescence results.

Statistics. Comparisons were obtained by ANOVA followed by Student-Newman-Keuls' test $(p<0.05)$.

Materials. APTRA-BTC-AM, mag-fura-5 AM, fura-2, Newport green diacetate, and 4-bromo (br)-A23187 were obtained from Molecular Probes (Eugene, OR). $\mathrm{Na}^{+}$-pyrithione, Ca-EDTA, $\mathrm{ZnCl}_{2}$, and TPEN were obtained from Sigma (St. Louis, MO). Zinquin-ethyl ester was obtained from Dojindo (Kumamoto, Japan).

\section{RESULTS}

Measurements of intracellular free $\mathrm{Zn}^{2+}$ in cortical neurons

Before settling on mag-fura-5, we explored the possible use of zinquin, Newport green, APTRA-BTC, or fura-2 in measuring $\left[\mathrm{Zn}^{2+}\right]_{\mathrm{i}}$ in cultured cortical neurons.

After $1 \mathrm{hr}$ loading at $37^{\circ} \mathrm{C}$ with $25 \mu \mathrm{M}$ zinquin-ethyl ester, cortical cultures exposed to $300 \mu \mathrm{M}$ kainate plus $300 \mu \mathrm{M} \mathrm{Zn^{2+ }}$ did not show a detectable increase in neuronal somatic zinquin fluorescence. Even exposure to the $\mathrm{Zn}^{2+}$ ionophore $20 \mu \mathrm{M} \mathrm{Na}{ }^{+}$pyrithione plus $1 \mathrm{~mm} \mathrm{Zn}^{2+}$ did not yield a zinquin signal, suggesting that the dye was not adequately loaded or cleaved. As a control, zinquin-loaded HEK 293 cells exposed to the same ionophore plus $\mathrm{Zn}^{2+}$ did exhibit a large increase in fluorescence, albeit distributed unevenly within the cells (data not shown).

Two other $\mathrm{Zn}^{2+}$-selective dyes, Newport green and APTRABTC, were loaded successfully into cortical neurons and exhibited strong responses to $\mathrm{Zn}^{2+}$ ionophore treatment. However, consistent with their low affinities for $\mathrm{Zn}^{2+}$ (see above), minimal responses were detectable after the physiological (probably pathophysiological) stimulus, $500 \mu \mathrm{M}$ kainate plus $300 \mu \mathrm{M} \mathrm{Zn}^{2+}$. We also examined the use of fura- 2 to detect intracellular $\mathrm{Zn}^{2+}$. However, beside the high sensitivity of fura- 2 for $\mathrm{Ca}^{2+}$, fura-2 also appeared too sensitive to $\mathrm{Zn}^{2+}$ for our purposes $\left(K_{\mathrm{d}}\right.$ for $\mathrm{Zn}^{2+}, \sim 2 \mathrm{nM}$ ) (Grynkiewicz et al., 1985). We found that fura-2loaded neurons exhibited a near saturating response to exposure to $300 \mu \mathrm{M}$ kainate plus $300 \mu \mathrm{M} \mathrm{Zn}^{2+}$ (in the absence of extracellular $\mathrm{Ca}^{2+}$ ).

As described above, we loaded mixed neuronal and glial cortical cell cultures with mag-fura-5 AM at a concentration of $3 \mu \mathrm{M}$ for 10 min at room temperature. Dye concentrations between 1 and 10 $\mu \mathrm{M}$ were explored, $1 \mu \mathrm{M}$ being too little for reliable measurements, and $10 \mu \mathrm{M}$ yielding reduced responses compared with 3 or $5 \mu \mathrm{M}$, suggestive of buffering (data not shown). Because neuronal cell bodies sat well above the underlying glial layer, it was possible to detect the 340/380 fluorescence ratio originating in these cell bodies with minimal interference from underlying glia. At rest, the neuronal somatic 340/380 fluorescence ratio was $\sim 1$ and insensitive to application of the membrane-permeant selective $\mathrm{Zn}^{2+}$ chelator TPEN $(100 \mu \mathrm{M})$ (Arslan et al., 1985) (Fig. 2, $\left.R_{\min }\right)$. Application of the selective $\mathrm{Zn}^{2+}$ ionophore $20 \mu \mathrm{M} \mathrm{Na}^{+}$-pyrithione (Zalewski et al., 1993), together with $1 \mathrm{~mm} \mathrm{Zn}^{2+}$ in HEPES buffer lacking $\mathrm{Ca}^{2+}$ and $\mathrm{Mg}^{2+}$, produced an increase in the neuronal somatic $340 / 380$ fluorescence ratio to 5.6 (Fig. 2, $R_{\max }$ ). If extracellular $\mathrm{Zn}^{2+}$ was omitted, no signal was seen (data not shown). Reapplication of $100 \mu \mathrm{M}$ TPEN produced a rapid fall in the 340/380 fluorescence signal back to baseline (Fig. 2). 


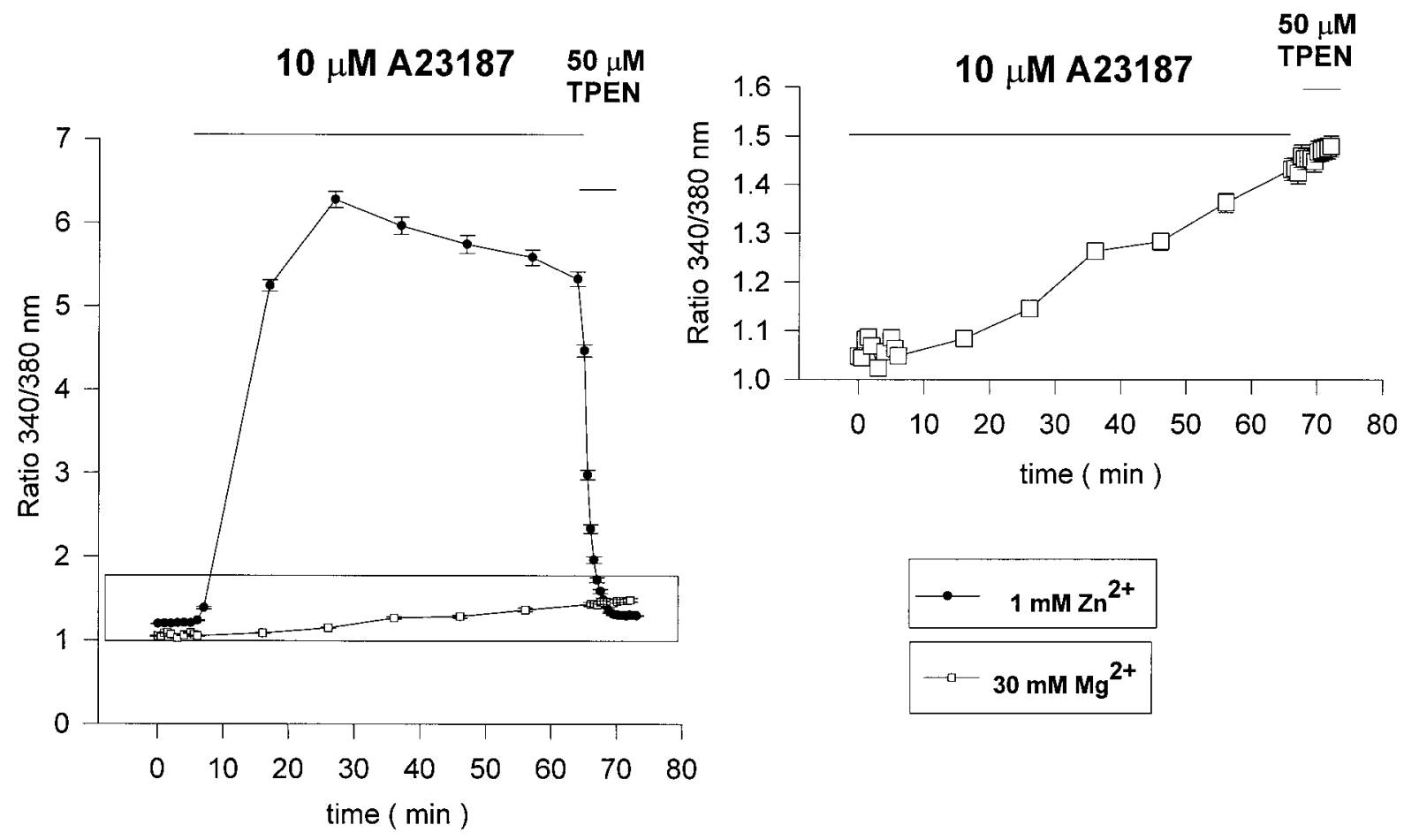

Figure 3. Comparison of mag-fura-5 sensitivity to $\mathrm{Mg}^{2+}$ and $\mathrm{Zn}^{2+} . A$, Exposure to br- $\mathrm{A} 23187(10 \mu \mathrm{M})$ for $60 \mathrm{~min}$ in the presence of $30 \mathrm{mM} \mathrm{Mg}{ }^{2+}$ (open symbols) or $1 \mathrm{mM} \mathrm{Zn}^{2+}$ (solid symbols). TPEN $\left(50 \mu \mathrm{M}\right.$ ) was added at the indicated time to quench the $\mathrm{Zn}^{2+}$ signal. $B$, Inset showing the same $\mathrm{Mg}^{2+}$ signal as in $A$, but at higher vertical gain; TPEN has no effect. Each point is the mean \pm SEM of at least 30 cells. Experiment is representative of three.

We considered it unlikely that this somatic mag-fura-5 signal was confounded by $\mathrm{Ca}^{2+}$ detection, given the absence of extracellular $\mathrm{Ca}^{2+}$ and the low affinity of the dye for $\mathrm{Ca}^{2+}$ (see above). Indeed, previous studies with mag-fura- 2 or mag-fura-5 did not detect neuronal somatic $\mathrm{Ca}^{2+}$ after glutamate exposure or electrical stimulation, even with extracellular $\mathrm{Ca}^{2+}$ present (Brocard et al., 1993; Petrozzino et al., 1995). A more serious possible confounding effect could derive from changes in intracellular $\mathrm{Mg}^{2+}$, which are in the millimolar range and may be increased by glutamate receptor activation even in the absence of extracellular $\mathrm{Mg}^{2+}$ (Brocard et al., 1993). However, consistent with the studies of Illner et al. (1992), even exposure to $30 \mathrm{~mm}$ $\mathrm{Mg}^{2+}$ in the presence of an ionophore, br-A23187, produced only a small change in the neuronal somatic 340/380 fluorescence ratio compared with the large change produced by $\mathrm{Zn}^{2+}$ in the same cells (Fig. 3). As a control, we demonstrated that the large $\mathrm{Zn}^{2+}$ signal, but not the small $\mathrm{Mg}^{2+}$ signal, was sensitive to application of $50 \mu \mathrm{M}$ TPEN (Fig. 3).

\section{Depolarization and $\mathrm{Na}^{+}$-dependent pathways involved in $\left[\mathrm{Zn}^{2+}\right]_{i}$ elevation}

Next we used mag-fura-5 to measure in cortical neurons accumulating $\mathrm{Zn}^{2+}$ under depolarizing conditions that might have pathophysiological relevance. Mixed cortical cell cultures were loaded with mag-fura-5 as above and placed into HEPES buffer lacking $\mathrm{Ca}^{2+}$ and $\mathrm{Mg}^{2+}$ (no chelators were added). The removal of external $\mathrm{Ca}^{2+}$ and $\mathrm{Mg}^{2+}$ produced no significant change ( $<20 \%$ change in the mean. $p>0.05$ with $n=4$ cells per condition) in the input resistance of the neurons either in resting condition $(-70 \mathrm{mV})$ or after depolarization $(-10 \mathrm{mV})$. Applica-

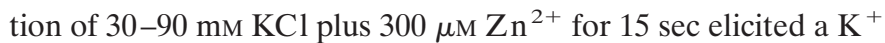
concentration-dependent and persistent (lasting $>60 \mathrm{~min}$ ) increase in $\left[\mathrm{Zn}^{2+}\right]_{\mathrm{i}}$ to $48 \pm 1.02 \mathrm{nM}$ that was terminated by application of $50 \mu \mathrm{M}$ TPEN, whereas application of $90 \mathrm{~mm} \mathrm{KCl}$ alone produced no response (Fig. $4 A, B$ ). The response to $90 \mathrm{~mm} \mathrm{KCl}$ could be blocked completely by concurrent application of the nonselective voltage-gated $\mathrm{Ca}^{2+}$ channel blockers gadolinium $\left(\mathrm{Gd}^{3+}, 10 \mu \mathrm{M}\right)$ and verapamil $(100 \mu \mathrm{M})$ and partially blocked by the selective blockers $\omega$-conotoxin GVIA (100 nM) and nimodipine $(1 \mu \mathrm{M})$ (Fig. $4 C)$. The observed reduction of the fluorescence produced by $\mathrm{Gd}^{3+}$ was not attributable to quenching, because the signal induced by exposure to $\mathrm{Na}^{+}$-pyrithione was not affected by $10 \mu \mathrm{M} \mathrm{Gd}^{3+}$ (data not shown).

Inclusion of $1.8 \mathrm{mM} \mathrm{Ca}^{2+}$, alone or together with $0.8 \mathrm{~mm}$ $\mathrm{Mg}^{2+}$, in the bathing medium reduced by approximately half the peak $\left[\mathrm{Zn}^{2+}\right]_{\mathrm{i}}$ response (sensitive to TPEN) induced by application of $90 \mathrm{~mm} \mathrm{KCl}$ plus $300 \mu \mathrm{M} \mathrm{Zn}{ }^{2+}$ (Fig. 4C). To test the hypothesis that $\mathrm{Zn}^{2+}$ might also enter neurons via reverse operation of an exchanger similar (or identical) to the $\mathrm{Na}^{+}-\mathrm{Ca}^{2+}$ exchanger, we loaded neurons with $\mathrm{Na}^{+}$by exposing the cultures to $1 \mathrm{~mm}$ ouabain for $15 \mathrm{~min}$. Removal of extracellular $\mathrm{Na}^{+}$ (replaced with $130 \mathrm{~mm}$ NMDG), together with application of 100 $\mu \mathrm{M} \mathrm{Zn}^{2+}$, still in the presence of ouabain, then produced over several minutes a slowly progressive increase in neuronal somatic $\left[\mathrm{Zn}^{2+}\right]_{\mathrm{i}}$ (Fig. $\left.5 B\right)$ that was larger than that produced by applica-

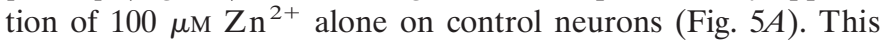
enhanced increase in $\left[\mathrm{Zn}^{2+}\right]_{i}$ was inhibited by the $\mathrm{Na}^{+}-\mathrm{Ca}^{2+}$ exchanger blockers benzamil-amiloride (BNZ) (Fig. 5C) and Dmethyl-benzamil-amiloride $(100 \mu \mathrm{M})$ (data not shown). To avoid 

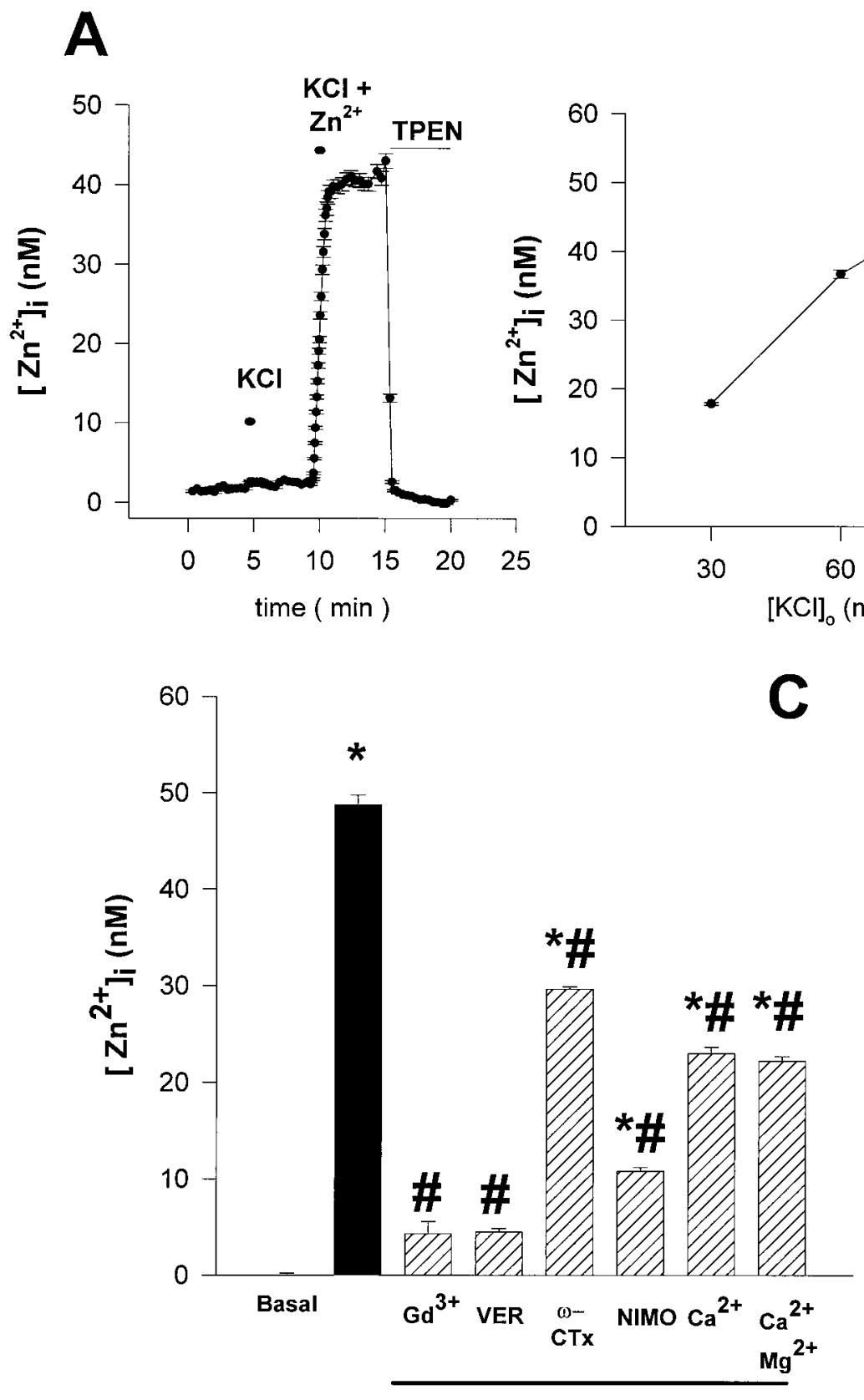

$90 \mathrm{mM} \mathrm{KCl}$
Figure 4. $\mathrm{KCl}$ evoked increase in $\left[\mathrm{Zn}^{2+}\right]_{\mathrm{i}} . A$, $\mathrm{KCl}(90 \mathrm{~mm})$ was applied for $15 \mathrm{sec}$ alone or in combination with $300 \mu \mathrm{M} \mathrm{Zn}{ }^{2+}$. TPEN $(50 \mu \mathrm{M})$ was added $5 \mathrm{~min}$ after the exposure to $\mathrm{Zn}^{2+}$. Each point is the mean \pm SEM of 49 cells. Experiment is representative of nine. B, Concentration-response curve of KCl-induced $\left[\mathrm{Zn}^{2+}\right]_{\mathrm{i}}$. Neurons were exposed for $15 \mathrm{sec}$ to indicated $\mathrm{KCl}$ concentrations. Each point is the mean \pm SEM of the peak $\left[\mathrm{Zn}^{2+}\right]_{i}$ levels obtained from at least three experiments. $C$, Pharmacological modulation of $90 \mathrm{~mm} \mathrm{KCl}$-induced increase in $\left[\mathrm{Zn}^{2+}\right]_{\mathrm{i}}$ in cortical neurons. $\left[\mathrm{Zn}^{2+}\right]_{\mathrm{i}}$ levels were measured before (Basal) or at the peak response after a $15 \mathrm{sec}$ exposure to $90 \mathrm{~mm}$ $\mathrm{KCl}$, alone or in the presence of $10 \mu \mathrm{M} \mathrm{Gd}^{3+}$, $100 \mu \mathrm{M}$ verapamil $(V E R), 100 \mathrm{nM} \omega$-conotoxinGVIA $(\omega-C T x), 1 \mu \mathrm{M}$ nimodipine $($ NIMO), $1.8 \mathrm{mM} \mathrm{Ca}^{2+}$, or $1.8 \mathrm{mM} \mathrm{Ca}^{2+}$ plus $0.8 \mathrm{~mm}$ $\mathrm{Mg}^{2+}$. Each column is pooled from three to nine experiments involving at least 40 cells per experiment. Asterisks indicate difference from basal level; \#, difference from $\mathrm{KCl}$-stimulated level, as determined by ANOVA and StudentNewman-Keuls' test $(p<0.05)$. activation of voltage-gated $\mathrm{Ca}^{2+}$ channels and glutamate receptors, $10 \mu \mathrm{M} \mathrm{Gd}{ }^{3+}, 10 \mu \mathrm{M} \mathrm{MK}-801$, and $10 \mu \mathrm{M}$ NBQX were present throughout the experiment. No detectable increase in $\left[\mathrm{Zn}^{2+}\right]_{\mathrm{i}}$ was produced by brief $(15 \mathrm{sec})$ application of an $\mathrm{Na}^{+}$. free solution containing $100-300 \mu \mathrm{M} \mathrm{Zn}^{2+}$.

To confirm that reversed operation of a neuronal exchanger like the $\mathrm{Na}^{+}-\mathrm{Ca}^{2+}$ exchanger could mediate $\mathrm{Zn}^{2+}$ influx, we used whole-cell voltage clamp to record the membrane current associated with the electrogenic exchanger operation. Under conditions favoring reverse operation, but limited by lack of extracellular $\mathrm{Ca}^{2+}\left(0 \mathrm{Na}^{+}, 0 \mathrm{Ca}^{2+}\right.$ in the bath; $60 \mathrm{mM} \mathrm{Na}^{+}, 0 \mathrm{Ca}^{2+}$ in the pipette), local application of $1 \mathrm{~mm}$ extracellular $\mathrm{Zn}^{2+}$ produced a reversible outward current shift $(23.0 \pm 4.4 \mathrm{pA}$ at -40 $\mathrm{mV}, \mathrm{SEM} ; n=4$ cells) (Fig. 6), resembling the $\mathrm{Na}^{+}-\mathrm{Ca}^{2+}$ exchanger current induced by $\mathrm{Ca}^{2+}$ under the same conditions
(Yu and Choi, 1997). This $\mathrm{Zn}^{2+}$-induced membrane current was blocked $70 \%$ by $100 \mu \mathrm{M}$ BNZ $(7.7 \pm 3.2 \mathrm{pA}, \mathrm{SEM} ; n=4$ cells $)$ (Fig. 6) and was totally blocked by $300 \mu \mathrm{M}$ BNZ ( $n=7$ cells) (data not shown). Furthermore, the current was not observed if $\mathrm{Na}^{+}$ was removed from the pipette solution (data not shown).

\section{Modulation of $\left[\mathrm{Zn}^{2+}\right]_{\mathrm{i}}$ in response to glutamate agonists}

Application of NMDA (10-300 $\mu \mathrm{M}, 15 \mathrm{sec})$ in the presence of 300 $\mu \mathrm{M}$ extracellular $\mathrm{Zn}^{2+}$ produced a quick increase in neuronal $\left[\mathrm{Zn}^{2+}\right]_{\mathrm{i}}$ in an NMDA concentration-dependent manner that was sensitive to the competitive NMDA antagonist D-APV $(100 \mu \mathrm{M})$ (Fig. 7). A maximal $\left[\mathrm{Zn}^{2+}\right]_{\mathrm{i}}$ of $31 \pm 0.97 \mathrm{nM}$ was induced by 300 $\mu \mathrm{M}$ NMDA. This NMDA-induced increase in $\left[\mathrm{Zn}^{2+}\right]_{\mathrm{i}}$ was only 

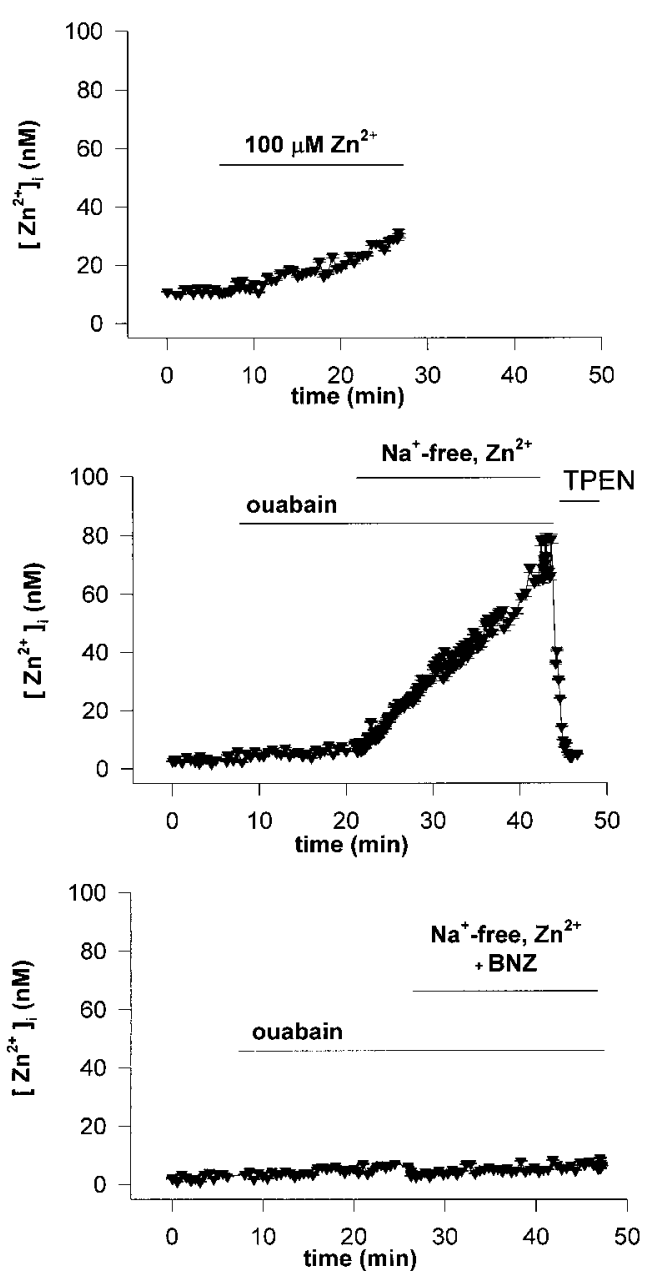

Figure 5. $\mathrm{Na}^{+}$-dependent $\Delta\left[\mathrm{Zn}^{2+}\right]_{\mathrm{i}}$. $A$, Fifteen minute exposure to 100 $\mu \mathrm{M} \mathrm{Zn}{ }^{2+}$ in the presence of $10 \mu \mathrm{M} \mathrm{Gd}{ }^{3+}, 10 \mu \mathrm{M} \mathrm{MK}-801$, and $10 \mu \mathrm{M}$ NBQX produced a gradual increase in $\left[\mathrm{Zn}^{2+}\right]_{\mathrm{i}}$. Each point is the mean \pm SEM of 58 cells in a single experiment, representative of three. $B$, Removal of extracellular $\mathrm{Na}^{+}$(equimolar substitution with NMDG) after the addition of $1 \mathrm{~mm}$ ouabain increases $\Delta\left[\mathrm{Zn}^{2+}\right]_{\mathrm{i}}$ induced by exposure to $100 \mu \mathrm{M} \mathrm{Zn}{ }^{2+}$. Each point is the mean \pm SEM of 57 cells in a single experiment, representative of six. $C$, Same as in $B$, but with the addition of $100 \mu \mathrm{M}$ BNZ. Each point is the mean \pm SEM of 56 cells in a single experiment, representative of four.
Control

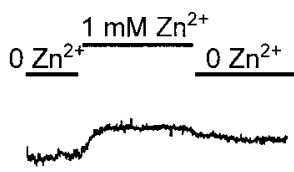

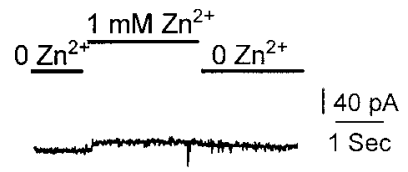

\section{Benzamil}

Figure 6. Exchanger current activated by external $\mathrm{Zn}^{2+}$ application. Left, Whole-cell recording from a cortical neuron in a bathing medium lacking $\mathrm{Na}^{+}$or $\mathrm{Ca}^{2+}$ (see Materials and Methods); the pipette solution contained $60 \mathrm{~mm} \mathrm{Na}{ }^{+} . \mathrm{ZnCl}_{2}(1 \mathrm{~mm})$ was applied in the bath as indicated. Holding potential $=-40 \mathrm{mV}$. Representative of four cells. Right, Same as in left, but with $100 \mu \mathrm{M} \mathrm{BNZ} \mathrm{in} \mathrm{the} \mathrm{bath.} \mathrm{Representative} \mathrm{of} \mathrm{four} \mathrm{cells.}$

partially sensitive to application of $10 \mu \mathrm{M} \mathrm{Gd}{ }^{3+}$ or removal of extracellular $\mathrm{Na}^{+}$(NMDG replacement).

Application of kainate $(10-300 \mu \mathrm{M}, 15 \mathrm{sec})$ in the presence of

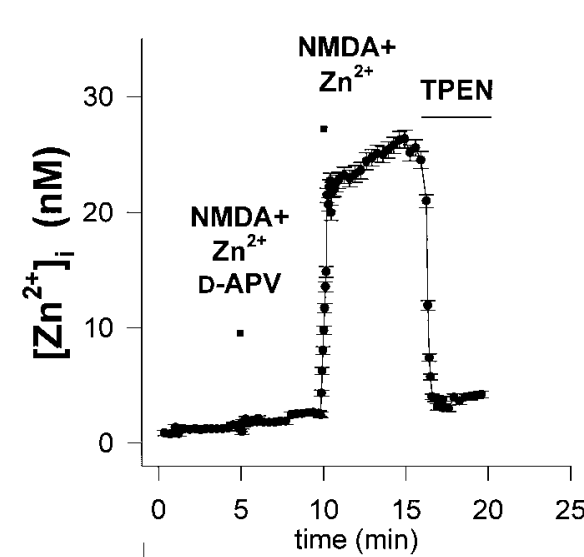

A

B
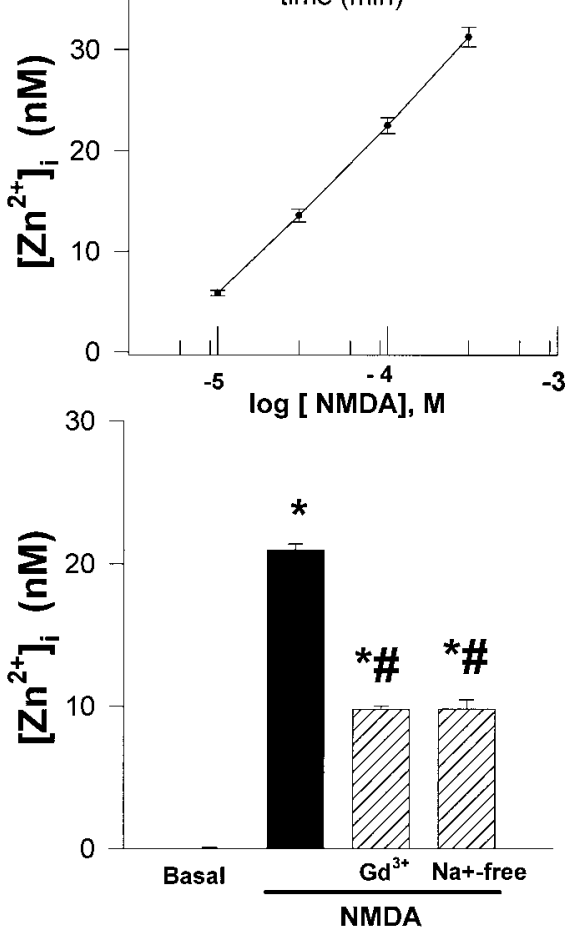

Figure 7. NMDA-induced increase in $\left[\mathrm{Zn}^{2+}\right]_{\mathrm{i}} . A$, NMDA $(100 \mu \mathrm{M}, 15$

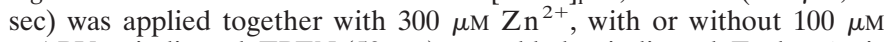
D-APV as indicated. TPEN $(50 \mu \mathrm{M})$ was added as indicated. Each point is the mean \pm SEM of 58 cells in a single experiment, representative of four. $B$, Concentration-response curve of NMDA-induced $\Delta\left[\mathrm{Zn}^{2+}\right]_{\mathrm{i}}$. The indicated concentrations of NMDA were applied for $15 \mathrm{sec}$ in the presence

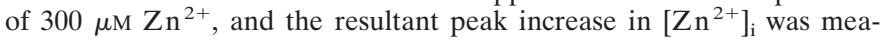
sured. Each concentration point was pooled from three experiments involving at least 40 cells per experiment; SEM bars are lost in the symbols. $C$, Pharmacological modulation of NMDA-induced $\Delta\left[\mathrm{Zn}^{2+}\right]_{\mathrm{i}} \cdot\left[\mathrm{Zn}^{2+}\right]_{\mathrm{i}}$ levels were measured before (basal) or at the peak response after a $15 \mathrm{sec}$ exposure to NMDA, in presence of $10 \mu \mathrm{M} \mathrm{Gd}{ }^{3+}$ or in absence of extracellular $\mathrm{Na}^{+}$(NMDG). Each column is pooled from three to nine experiments involving at least 40 cells per experiment. Asterisks indicate difference from basal level; \#, difference from NMDA-stimulated levels, as determined by ANOVA and Student-Newman-Keuls' test $(p<0.05)$.

$300 \mu \mathrm{M}$ extracellular $\mathrm{Zn}^{2+}$ also produced a quick increase in neuronal $\left[\mathrm{Zn}^{2+}\right]_{\mathrm{i}}$ in a concentration-dependent manner, sensitive to $10 \mu \mathrm{M}$ NBQX (Fig. 8). To determine the extent to which the $\mathrm{Zn}^{2+}$ entry triggered by kainate receptor stimulation was mediated indirectly via voltage-gated $\mathrm{Ca}^{2+}$ channels, we exposed neurons to kainate in an $\mathrm{Na}^{+}$-free solution (NMDG) (to prevent $\mathrm{Na}^{+}$entry-mediated membrane depolarization and consequent activation of voltage-gated $\mathrm{Ca}^{2+}$ channels). 

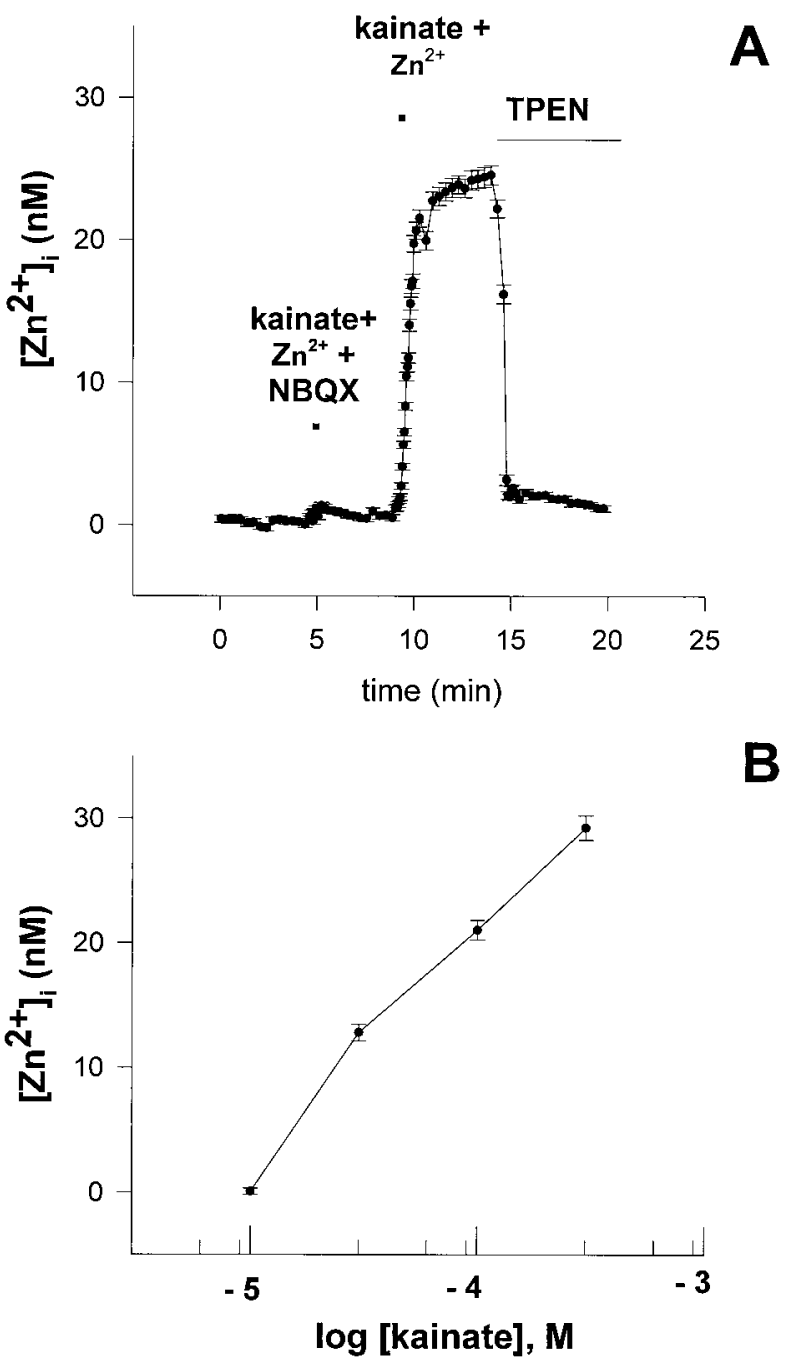

Figure 8. Kainate-induced $\Delta\left[\mathrm{Zn}^{2+}\right]_{\mathrm{i}} . A$, Kainate $(100 \mu \mathrm{M}, 15 \mathrm{sec})$ was

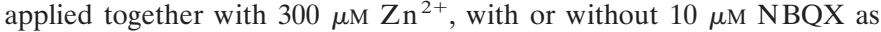
indicated. TPEN $(50 \mu \mathrm{M})$ was added as indicated. Each point is the mean \pm SEM of 61 cells in a single experiment representative of three. $B$ Concentration-response curve of kainate-induced elevation in $\left[\mathrm{Zn}^{2+}\right]_{\mathrm{i}}$ The indicated concentrations of kainate were applied for $15 \mathrm{sec}$ in the presence of $300 \mu \mathrm{M}$ of $\mathrm{Zn}^{2+}$, and the resultant peak increase in $\left[\mathrm{Zn}^{2+}\right]_{\mathrm{i}}$ was measured. Each concentration point was pooled from three experiments involving at least 40 cells per experiment; SEM bars are lost in the symbols.

Removal of $\mathrm{Na}^{+}$inhibited kainate-induced increase in $\left[\mathrm{Zn}^{2+}\right]_{\mathrm{i}}$ in most, but not all, neurons. In three pooled experiments, application of $50 \mu \mathrm{M}$ kainate in the $\mathrm{Na}^{+}$-free solution caused $\left[\mathrm{Zn}^{2+}\right]_{\mathrm{i}}$ to rise strongly in 17 of $156(10.8 \%)$ neurons (Fig. 9A,B). The microscope fields were marked, and the cultures were subsequently subjected to staining for kainate-activated cobalt uptake ("Co ${ }^{2+}$-positive neurons"), a marker for the functional expression of AMPA or kainate receptors gating channels with high $\mathrm{Ca}^{2+}$ permeability (Pruss et al., 1991, Turetsky et al., 1994; Yin et al., 1994). There was a one-to-one correlation between strong $\left[\mathrm{Zn}^{2+}\right]_{\mathrm{i}}$-responsiveness in $\mathrm{Na}^{+}$-free conditions and $\mathrm{Co}^{2+}$ positivity (Fig. 9, $C, D$ ).

Like the removal of extracellular $\mathrm{Na}^{+}$, inhibition of voltagegated $\mathrm{Ca}^{2+}$ channels with $10 \mu \mathrm{M} \mathrm{Gd^{3+ }}$ or $1 \mu \mathrm{M}$ nimodipine strongly attenuated the kainate-induced increase in $\left[\mathrm{Zn}^{2+}\right]_{i}$ in most of the cells (Fig. 10). However, in a small number of neurons, the increase in $\left[\mathrm{Zn}^{2+}\right]_{\mathrm{i}}$ remained near the control value (Fig. 10), supporting the idea that $\mathrm{Zn}^{2+}$ influx also occurred directly through AMPA/kainate receptor-gated channels, possessing high $\mathrm{Ca}^{2+}$ permeability.

\section{DISCUSSION}

Taking a lead from Simons (1993), who used mag-fura-2 to measure $\mathrm{Zn}^{2+}$ concentrations in solution, we demonstrate here that mag-fura-5 can be used to follow $\left[\mathrm{Zn}^{2+}\right]_{\mathrm{i}}$ in living cortical neurons. Three lines of evidence indicate that the mag-fura- 5 ratio signal we observed indeed reflects increases in $\left[\mathrm{Zn}^{2+}\right]_{i}$. First, the signal was induced by application of a $\mathrm{Zn}^{2+}$-selective ionophore, $\mathrm{Na}^{+}$-pyrithione, only when extracellular $\mathrm{Zn}^{2+}$ was present. Second, this $\mathrm{Na}^{+}$-pyrithione $/ \mathrm{Zn}^{2+}$ signal was quenched rapidly by the specific cell-permeable $\mathrm{Zn}^{2+}$ chelator TPEN. Third, conclusions regarding routes of $\mathrm{Zn}^{2+}$ entry reached here are consistent with previous observations using TSQ fluorescence or ${ }^{65} \mathrm{Zn}^{2+}$ accumulation to assess $\mathrm{Zn}^{2+}$ influx.

The idea that depolarizing stimuli can drive $\mathrm{Zn}^{2+}$ entry through $\mathrm{Gd}^{3+}$ - and nimodipine-sensitive voltage-gated channels fits with toxicity experiments (Weiss et al., 1993; Freund and Reddig, 1994; Manev et al., 1997), as well as with recent experiments from our laboratory tracking depolarization-induced neuronal ${ }^{65} \mathrm{Zn}^{2+}$ influx in the same cultures $(\mathrm{H}$. S. Ying, S. Farhangrazi, C. S. Ling, D. Lobner, L. M. T. Canzoniero, S. L. Sensi, J. Y. Koh, C. T. Sheline, and D. W. Choi, unpublished observations). Although $\mathrm{Zn}^{2+}$, like other transition metals, is commonly considered an inhibitor of $\mathrm{Na}^{+}$and $\mathrm{Ca}^{2+}$-voltage-gated channels (Harrison and Gibbons, 1994), such inhibition does not exclude slow permeation. $\mathrm{Zn}^{2+}$ sheds its water of hydration at a speed intermediate between that of $\mathrm{Ca}^{2+}$ and $\mathrm{Mg}^{2+}$ (Diebler et al., 1969) and permeates through $\mathrm{Ca}^{2+}$ channels on invertebrate neurons (Fukuda and Kawa, 1977), chromaffin cells (Vega et al., 1994), and myocytes (Atar et al., 1995). Wang and Quastel (1990) attributed the complex effects of extracellular $\mathrm{Zn}^{2+}$ on acetylcholine release at the neuromuscular junction to permeation through nerve terminal $\mathrm{Ca}^{2+}$ channels. It will be interesting in the future to see whether any subset of the voltage-gated channels passing $\mathrm{Zn}^{2+}$ prefer $\mathrm{Zn}^{2+}$ over $\mathrm{Ca}^{2+}$ and are really thus " $\mathrm{Zn}^{2+}$ channels."

The idea that $\mathrm{Zn}^{2+}$ can also permeate through NMDA receptor-gated $\mathrm{Ca}^{2+}$ channels (Koh and Choi, 1994) is supported by present data showing that the NMDA-induced $\left[\mathrm{Zn}^{2+}\right]_{\mathrm{i}}$ signal was only partly sensitive to $\mathrm{Gd}^{3+}$ addition or extracellular $\mathrm{Na}^{+}$ removal. The speed of this response (seconds) argues against any large mediation by exchange with $\mathrm{Na}^{+}$, a mechanism requiring several minutes to produce substantial elevations in $\left[\mathrm{Zn}^{2+}\right]_{\mathrm{i}}$ (see below). $\mathrm{Zn}^{2+}$ mediates a voltage-sensitive, fast flicker block of NMDA receptor-gated channels (Christine and Choi, 1990). Possibly, the onset of this block reflects plugging of the channel by $\mathrm{Zn}^{2+}$, and relief of block reflects permeation of $\mathrm{Zn}^{2+}$.

It is likely that $\mathrm{Zn}^{2+}$ similarly passes through the $\mathrm{Ca}^{2+}$. permeable AMPA/kainate receptors expressed on a small minority of cortical neurons, the "cobalt-positive" cells (Pruss et al., 1991; Turetsky et al., 1994), reflecting (in the case of AMPA receptors) lack of an edited form of GluRB/GluR2 (Hollmann et al., 1991; Verdoorn et al., 1991). This conclusion fits with that reached by Yin and Weiss (1995), who used TSQ to assess $\left[\mathrm{Zn}^{2+}\right]_{\mathrm{i}}$ qualitatively. Recent evidence suggests that cobaltpositive cortical neurons are primarily GABAergic interneurons (Jonas et al., 1994; Yin et al., 1994), raising the interesting 


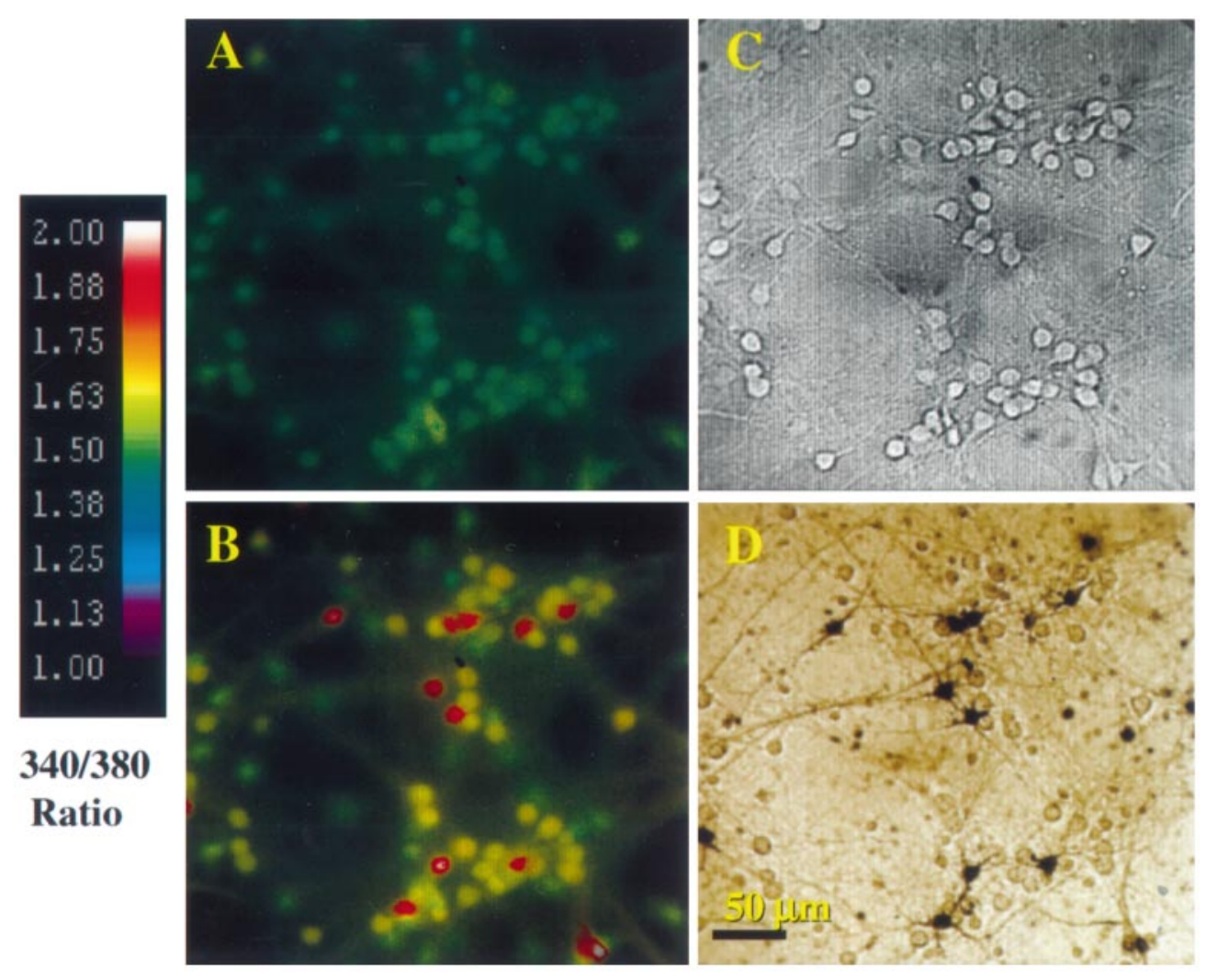

Figure 9. $\left[\mathrm{Zn}^{2+}\right]_{\mathrm{i}}$ elevation in cobaltpositive neurons. $A, B$, Pseudocolor images depicting $\left[\mathrm{Zn}^{2+}\right]_{\mathrm{i}}$, as mag-fura-5 $340 / 380$ ratio values as indicated in the scale, in cortical neurons before $(A)$ and after $(B)$ exposure $(15 \mathrm{sec})$ to $50 \mu \mathrm{M}$ kainate in the presence of $100 \mu \mathrm{M} \mathrm{Zn^{2+ }}$ but in the absence of extracellular $\mathrm{Na}^{+}$ (NMDG replacement). $\left[\mathrm{Zn}^{2+}\right]_{\mathrm{i}}$ elevation in a minority subpopulation of neurons can be seen. $C$, Phase-contrast micrograph of the same field. $D$, Kainateactivated cobalt staining of the same field. A one-to-one correlation is seen between neurons responding with a large $\Delta\left[\mathrm{Zn}^{2+}\right]_{\mathrm{i}}$ in the absence of extracellular $\mathrm{Na}^{+}$and cobalt-positivity. Scale bar, $50 \mu \mathrm{m}$. possibility that inhibitory interneurons may be especially vulnerable to $\mathrm{Zn}^{2+}$-induced death under conditions in which AMPA receptors are activated. Furthermore, the ability of certain AMPA receptors to mediate toxic $\mathrm{Zn}^{2+}$ entry may provide a link between previous observations implicating AMPA receptor overactivation (Pellegrini-Giampietro et al., 1992; Sheardown et al., 1993) and $\mathrm{Zn}^{2+}$ entry (Koh et al., 1996) in selective neuronal death after transient global ischemia.

Beside entry through voltage- and agonist-gated $\mathrm{Ca}^{2+}$ channels, we provide evidence here for the possibility that $\mathrm{Zn}^{2+}$ may also enter depolarized neurons via BNZ-sensitive exchange with intracellular $\mathrm{Na}^{+}$. Although it is possible that a unique " $\mathrm{Na}^{+}-$ $\mathrm{Zn}^{2+}$ " exchanger mediates $\mathrm{Zn}^{2+}$ entry in exchange for $\mathrm{Na}^{+}$ efflux (or vice versa under different conditions), it is conservative to postulate that $\mathrm{Zn}^{2+}$ can substitute for $\mathrm{Ca}^{2+}$ in the operation of the known neuronal $\mathrm{Na}^{+}-\mathrm{Ca}^{2+}$ exchanger (Blaustein et al., 1991, 1996; Yu and Choi, 1997), as shown for $\mathrm{Sr}^{2+}$ and $\mathrm{Ba}^{2+}$ in cardiac sarcolemmal vesicles (Tibbits and Philipson, 1985) and for $\mathrm{Mn}^{2+}$ and $\mathrm{Cd}^{2+}$ in ferret red blood cells (Frame and Milanick, 1991). Such exchanger-mediated $\mathrm{Zn}^{2+}$ entry would be favored when the normal membrane $\mathrm{Na}^{+}$gradient is diminished and membrane potential is depolarized, as occurs during brain ischemia. The outward current detected here in association with $\mathrm{Zn}^{2+}$ entry is consistent with the electrogenic nature of the exchanger, with a typical stochiometry of one $\mathrm{Ca}^{2+}$ (or $\mathrm{Zn}^{2+}$ ion) exchanged for three $\mathrm{Na}^{+}$ions.

We think it is unlikely that the mag-fura-5 signal measured here was substantially confounded by detection of $\mathrm{Ca}^{2+}$ or $\mathrm{Mg}^{2+}$. In the absence of extracellular $\mathrm{Ca}^{2+}$, previous studies have not suggested that $\left[\mathrm{Ca}^{2+}\right]_{\mathrm{i}}$ in neuronal soma would rise to the high micromolar levels needed to activate mag-fura-5 $\left(K_{\mathrm{d}}, \sim 20 \mu \mathrm{M}\right)$ (Petrozzino et al., 1995). $\mathrm{Mg}^{2+}$ is a greater possibility, because intracellular levels at rest are in the $0.5-1 \mathrm{~mm}$ range (Brocard et al., 1993), already approaching the $K_{\mathrm{d}}$ of the dye for $\mathrm{Mg}^{2+}(2.6$ $\mathrm{mm}$ ) (Haugland, 1996). However, although some baseline $\mathrm{Mg}^{2+}$ binding is therefore probable, when we forced $\mathrm{Mg}^{2+}$ entry by increasing extracellular $\mathrm{Mg}^{2+}$ to $30 \mathrm{~mm}$ in the presence of a suitable ionophore, br-A23187, only small ratio shifts in magfura-5 fluorescence occurred, and these shifts, unlike the shifts induced by depolarizing neurons in the presence of extracellular $\mathrm{Zn}^{2+}$, were insensitive to TPEN. We cannot absolutely rule out the complex possibility that $\mathrm{Zn}^{2+}$ entry somehow caused massive intracellular $\mathrm{Mg}^{2+}$ release analogous to the $\mathrm{Ca}^{2+}$-triggered intracellular $\mathrm{Mg}^{2+}$ release delineated by Brocard et al. (1993). However, no elevation of $\left[\mathrm{Mg}^{2+}\right]_{\mathrm{i}}$ was seen by Brocard et al. (1993) in cortical neurons exposed to depolarizing conditions such as veratridine or kainate.

The nominal absence of $\mathrm{Ca}^{2+}$ or $\mathrm{Mg}^{2+}$ used in many of the present experiments to minimize confounding detection of $\mathrm{Ca}^{2+}$ or $\mathrm{Mg}^{2+}$ likely exaggerated $\mathrm{Zn}^{2+}$ influx by over that which would normally occur in the presence of physiological concentrations of these ions. The absence of extracellular $\mathrm{Ca}^{2+}$ can reduce the selectivity of calcium channels on frog muscle cells (Almers et al., 1984) or potassium channels on squid neurons (Armstrong and Barneo, 1987), although because we performed our experiments without added chelators, enough $\mathrm{Ca}^{2+}$ and $\mathrm{Mg}^{2+}$ may have been present to maintain channel selectivity. In any case, previous studies demonstrated that $\left[\mathrm{Ca}^{2+}\right]_{\mathrm{o}}$ inversely affects $\mathrm{Zn}^{2+}$ toxicity (Koh and Choi, 1994). Moreover, a direct inhibition of ${ }^{65} \mathrm{Zn}^{2+}$ influx by extracellular $\mathrm{Ca}^{2+}\left(\mathrm{IC}_{50}=416 \mu \mathrm{M}\right.$; Hill coefficient $=$ 1.01) has been demonstrated in our culture system (H. S. Ying, S. Farhangrazi, C. S. Ling, D. Lobner, L. M. T. Canzoniero, S. L. Sensi, J. Y. Koh, C. T. Sheline, and D. W. Choi, unpublished observations), and we found here a substantial decrease $(\sim 50 \%)$ in peak $\left[\mathrm{Zn}^{2+}\right]_{\mathrm{i}}$ when depolarization by $90 \mathrm{~mm} \mathrm{KCl}$ was evoked in the presence of a physiological concentration $(1.8 \mathrm{~mm})$ of 


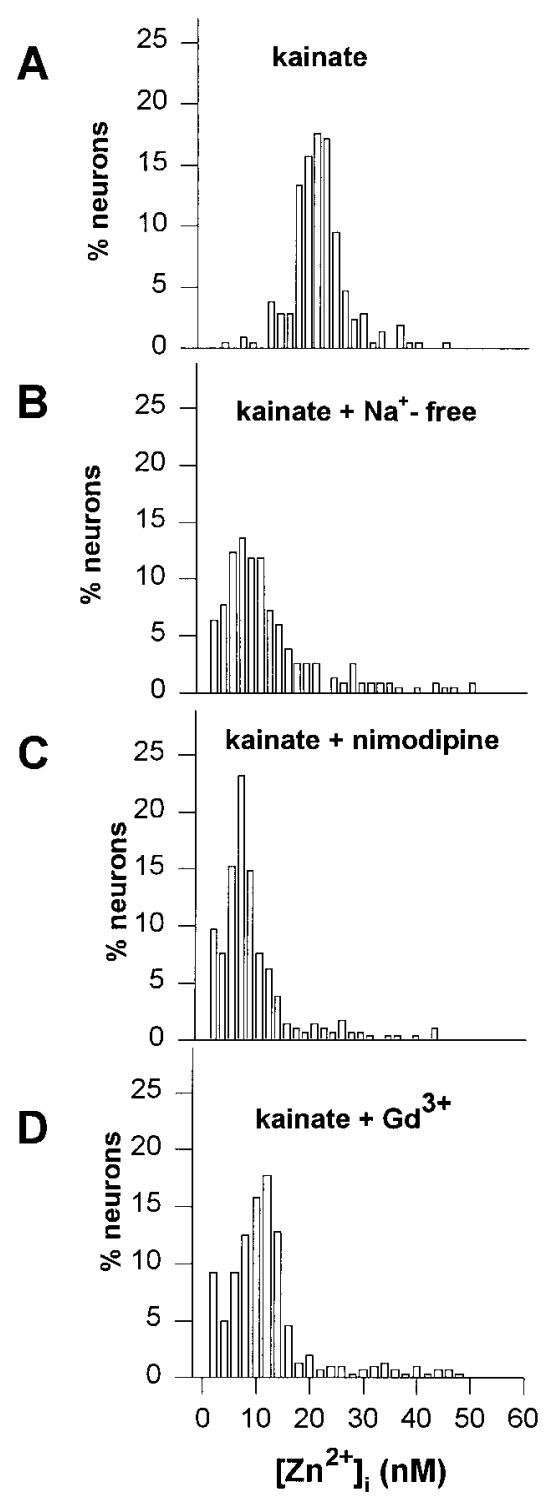

Figure 10. Pharmacological modulation of kainate-induced elevation in $\left[\mathrm{Zn}^{2+}\right]_{\mathrm{i}}$. Histograms show the fraction of the cortical neuronal population exhibiting the indicated peak $\left[\mathrm{Zn}^{2+}\right]_{\mathrm{i}}$ response during a $15 \mathrm{sec}$ exposure

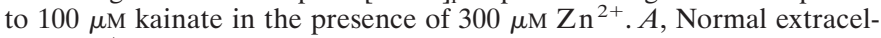
lular $\mathrm{Na}^{+}$(mean \pm SEM, $23.5 \pm 0.4 \mathrm{nM} ; n=210$ cells); $B$, in the absence of extracellular $\mathrm{Na}^{+}(12.9 \pm 0.8 ; n=235) ; C$, in the presence of $1 \mu \mathrm{M}$ nimodipine $(9.6 \pm 0.5 ; n=289$ cells $) ; D$, in the presence of $10 \mu \mathrm{M} \mathrm{Gd}{ }^{3+}$ (11.2 nM $\pm 0.5 ; n=305$ cells). For each condition, the data were pooled from at least three experiments. All the treated conditions were statistically different from the control condition, as determined by ANOVA and Student-Newman-Keuls' test $(p<0.05)$.

extracellular $\mathrm{Ca}^{2+}$ with or without $0.8 \mathrm{mM} \mathrm{Mg}^{2+}$. However, present experiments may model conditions occurring in the ischemic brain in vivo, in which extracellular calcium dramatically drops (Hansen, 1985) and extracellular $\mathrm{Zn}^{2+}$ likely rises (Koh et al., 1996). That is, if we are correct in postulating that most of the mag-fura-5 fluorescence shift observed in the present experiments can be interpreted as an increase in $\left[\mathrm{Zn}^{2+}\right]_{i}$, then present observations provide a direct estimate $(10-30 \mathrm{nM})$ of neuronal somatic $\left[\mathrm{Zn}^{2+}\right]_{\mathrm{i}}$ under pathophysiological conditions of NMDA or kainate activation when extracellular $\mathrm{Zn}^{2+}$ is abundantly present and extracellular $\mathrm{Ca}^{2+}$ is low (Figs. 7, 8).
Such increases would be produced easily by the total $\mathrm{Zn}^{2+}$ accumulating in cultured cortical neurons exposed to high $\mathrm{K}^{+}$

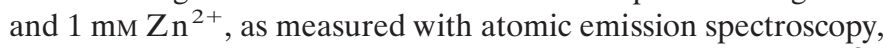
which is sufficient to produce a calculated intracellular $\mathrm{Zn}^{2+}$ concentration of $\sim 1 \mathrm{~mm}$ in the absence of $\mathrm{Zn}^{2+}$ sequestration or binding (H. S. Ying, S. Farhangrazi, C. S. Ling, D. Lobner, L. M. T. Canzoniero, S. L. Sensi, J. Y. Koh, C. T. Sheline, and D. W. Choi, unpublished observations). Most likely, the bulk of the $\mathrm{Zn}^{2+}$ entering depolarized neurons does not remain free in the cytosol, but rather is taken up into organelles (Palmiter et al., 1996) or binds to macromolecules such as metallothioneins (Masters et al., 1994; Ebadi et al., 1995; Maret, 1995). Erickson et al. (1997) demonstrated that deletion of the gene coding for metallothionein-III increased the CA3 neuronal death associated with kainate-induced seizures, a process likely mediated at least in part by toxic zinc translocation from mossy fiber terminals into CA3 neurons (Sloviter, 1985; Koh et al., 1996) (S. W. Suh, J. Y. Koh, and D. W. Choi, unpublished observations). Furthermore, present measurements of somatic fluorescence would not be expected to detect $\mathrm{Zn}^{2+}$ entering in neurites.

Previous determinations of $\left[\mathrm{Zn}^{2+}\right]_{\mathrm{i}}$ in nonneuronal cells have generally reported concentrations lower than those found here. In erythrocytes, Simons (1991) used ${ }^{65} \mathrm{Zn}^{2+}$ flux to arrive at an estimate of 1.5-32 pM for $\left[\mathrm{Zn}^{2+}\right]_{\mathrm{i}}$, depending on the ionic composition of the extracellular solution; in human leukemic cells, a $\left[\mathrm{Zn}^{2+}\right]_{\mathrm{i}}$ of $\sim 1 \mathrm{nM}$ was determined by ${ }^{19} \mathrm{~F}$ nuclear magnetic resonance (Adebodun and Post, 1995). Additionally, fura-2monitored $\left[\mathrm{Zn}^{2+}\right]_{\mathrm{i}}$ increased from 0.4 to $2 \mathrm{~nm}$ in chromaffin cells on electrical stimulation (Atar et al., 1995). However, recently zinquin was used to estimate concentrations of $\sim 20-50 \mu \mathrm{M}$ for $\left[\mathrm{Zn}^{2+}\right]_{\mathrm{i}}$ in splenocytes and thymocytes at rest (Zalewski et al., 1993 ) and of 0.6 to $2.7 \mu \mathrm{M}$ in hepatocytes removed from rats fed a high-zinc diet (Brand and Kleineke, 1996).

In summary, we make one comment about methods and one comment about cellular $\mathrm{Zn}^{2+}$ homeostasis. First, although magfura-5 appears to provide a reasonable tool for measuring $\left[\mathrm{Zn}^{2+}\right]_{\mathrm{i}}$ dynamically in living neurons, especially when extracellular $\mathrm{Ca}^{2+}$ and $\mathrm{Mg}^{2+}$ are absent, such measurements will need to be interpreted cautiously, and all measurements made with magfura-5 will need confirmation once truly $\mathrm{Zn}^{2+}$-selective ratioable dyes are available. Second, the observations presented here add to available evidence suggesting that $\mathrm{Zn}^{2+}$ can enter central neurons by multiple routes, likely in large part overlapping with routes of $\mathrm{Ca}^{2+}$ entry. Although the significance of this $\mathrm{Zn}^{2+}$ entry is most clearly defined in terms of contributing to the pathophysiology of neuronal degeneration in certain disease states, these mechanisms may also facilitate $\mathrm{Zn}^{2+}$ entry during normal synaptic transmission, permitting "transsynaptic messenger" $\mathrm{Zn}^{2+}$ to modulate a variety of processes in the postsynaptic neurons, such as signal transduction, transport processes, and gene expression (O’Halloran, 1993; Vallee and Falchuk, 1993).

\section{REFERENCES}

Adebodun F, Post JF (1995) Role of intracellular free Ca(II) and Zn(II) in dexamethasone-induced apoptosis and dexamethasone resistance in human leukemic CEM cell lines. J Cell Physiol 163:80-86.

Almers W, McClesley EW, Palade PT (1984) A non-selective cation conductance in frog muscle membrane blocked by micromolar external calcium ions. J Physiol (Lond) 353:565-583.

Andrews JC, Nolan JP, Hammerstedt RH, Bavister BD (1995) Characterization of $N$-(6-methoxy-8-quinolyl)-P-toluenesulfonamide for the detection of zinc in living sperm cells. Cytometry 21:153-159.

Armstrong CM, Lopez-Barneo J (1987) External calcium ions are re- 
quired for potassium channel gating in squid neurons. Science 236:712-714.

Arslan P, Di Virgilio F, Beltrame M, Tsien RY, Pozzan T (1985) Cytosolic $\mathrm{Ca}^{2+}$ homeostasis in Erlich and Yoshida carcinomas. J Biol Chem 260:2719-2727.

Assaf SY, Chung SH (1984) Release of endogenous $\mathrm{Zn}^{2+}$ from brain tissue during activity. Nature 308:734-736.

Atar D, Backx PH, Appel MM, Gao WD, Marban E (1995) Excitationtranscription coupling mediated by zinc influx through voltagedependent calcium channels. J Biol Chem 270:2473-2477.

Berg JM, Shi Y (1996) The galvanization of biology: a growing appreciation for the roles of zinc. Science 271:1081-1085.

Blaustein MP, Goldman WF, Fontana G, Krueger BK, Santiago EM, Steele TD, Weiss DN, Yarowsky PJ (1991) Physiological roles of the sodium-calcium exchanger in nerve and muscle. Ann NY Acad Sci 639:254-274.

Blaustein MP, Fontana G, Rogowski RS (1996) The $\mathrm{Na}(+)-\mathrm{Ca} 2+$ exchanger in rat brain synaptosomes. Kinetics and regulation. Ann NY Acad Sci 779:300-317.

Brand IA, Kleineke J (1996) Intracellular zinc movement and its effect on the carbohydrate metabolism of isolated rat hepatocytes. J Biol Chem 271:1941-1949.

Brocard JB, Rajdev S, Reynolds IJ (1993) Glutamate-induced increase in intracellular free $\mathrm{Mg}^{2+}$ in cultured cortical neurons. Neuron 11:751-757.

Budde T, Minta A, White JA, Kay AR (1997) Imaging free zinc in synaptic terminals in live hippocampal slices. Neuroscience 79:347-358.

Choi DW, Maulucci-Gedde MA, Kriegstein AR (1987) Glutamate neurotoxicity in cortical cell culture. J Neurosci 7:357-368.

Christine CW, Choi DW (1990) Effect of zinc on NMDA receptormediated channel currents in cortical neurons. J Neurosci 10:108-116.

Danscher G (1984) Do the Timm sulphide silver method and the selenium method demonstrate zinc in the brain? In: The neurobiology of zinc (Frederickson CJ, Howell GA, Kasarskis EJ, eds), pp 273-287. New York: Liss.

Denny MF, Atchison WD (1994) Methylmercury-induced elevations in intrasynaptosomal zinc concentrations: an ${ }^{19}$ F-NMR study. J Neurochem 63:383-386.

Diebler H, Eigen M, Ilgenfritz G, Maass G, Winkler R (1969) Kinetics and mechanism of reactions of main group metal ions with biological carriers. Pure Appl Chem 20:93-115.

Ebadi M, Iversen PL, Hao R, Cerutis DR, Rojas P, Happe HK, Murrin LC, Pfeiffer RF (1995) Expression and regulation of brain metallothionein. Neurochem Int 27:1-22.

Erickson JC, Hollopeter G, Thomas SA, Froelick GJ, Palmiter RD (1997) Disruption of the metallothionein-III gene in mice: analysis of brain zinc, behavior, and neuron vulnerability to metals, aging, and seizures. J Neurosci 17:1271-1281.

Frame MD, Milanick MA (1991) Mn and Cd transport by the $\mathrm{Na}-\mathrm{Ca}$ exchanger of ferret red blood cells. Am J Physiol 261:C467-C475.

Frederickson CJ (1989) Neurobiology of zinc and zinc-containing neurons. Int Rev Neurobiol 31:145-238.

Frederickson CJ, Moncrieff DW (1994) Zinc-containing neurons. Biol Signals 3:127-139.

Frederickson CJ, Kasarskis EJ, Ringo D, Frederickson RE (1987) A quinoline fluorescence method for visualization and assaying the histochemically reactive zinc (bouton zinc) in the brain. J Neurosci Methods 20:91-103.

Frederickson CJ, Hernandez MD, McGinty JF (1989) Translocation of zinc may contribute to seizure-induced death of neurons. Brain Res 480:317-321.

Freund WD, Reddig S (1994) AMPA/ $\mathrm{Zn}^{2+}$-induced neurotoxicity in rat primary cortical cultures: involvement of L-type calcium channels. Brain Res 654:257-264.

Fukuda J, Kawa K (1977) Permeation of manganese, cadmium, zinc, beryllium through calcium channels of an insect muscle membrane. Science 196:309-311.

Grynkiewicz G, Poenie M, Tsien RY (1985) A new generation of $\mathrm{Ca}^{2+}$ indicators with greatly improved fluorescence properties. J Biol Chem 260:3440-3450.

Hansen AJ (1985) Effect of anoxia on ion distribution in the brain. Physiol Rev 65:101-148.

Harrison NL, Gibbons SJ (1994) $\mathrm{Zn}^{2+}$ : an endogenous modulator of ligand-and voltage-gated ion channels. Neuropharmacology 33:935-952.
Haugland RP (1996) Handbook of fluorescent probes and research chemicals, Ed 6, pp 531-540. Eugene, OR: Molecular Probes.

Hechtenberg S, Beyersmann D (1993) Differential control of free calcium and free zinc levels in isolated bovine liver nuclei. Biochem $\mathbf{J}$ 289:757-760.

Hollmann M, Hartley M, Heinemann S (1991) $\mathrm{Ca}^{2+}$ permeability of KA-AMPA-gated glutamate receptor channels depends on subunit composition. Science 252:851-853.

Howell GA, Welch MG, Frederickson CJ (1984) Stimulation-induced uptake and release of zinc in hippocampal slices. Nature 308:736-738.

Illner H, McGuigan JAS, Luthi D (1992) Evaluation of mag-fura-5, the new fluorescent indicator for free magnesium measurements. Pflügers Arch 422:179-184.

Jonas P, Racca C, Sakmann B, Seeburg PH, Monyer H (1994) Differences in $\mathrm{Ca}^{2+}$ permeability of AMPA-type glutamate receptor channels in neocortical neurons caused by differential GluR-B subunit expression. Neuron 12:1281-1289.

Koh JY, Choi DW (1994) Zinc toxicity on cultured cortical neurons involvement of $N$-methyl-D-aspartate. Neuroscience 60:1049-1057.

Koh JY, Suh SW, Gwag BJ, He YY, Hsu CY, Choi DW (1996) The role of zinc in selective neuronal death after transient global cerebral ischemia. Science 272:1013-1016.

Manev H, Kharlamov E, Uz T, Mason RP, Cagnoli CM (1997) Characterization of zinc-induced neuronal death in primary cultures of rat cerebellar granule cells. Exp Neurol 146:171-178.

Maret W (1995) Metallothionein/disulfide interactions, oxidative stress, and the mobilization of cellular zinc. Neurochem Int 27:111-117.

Masters BA, Quaife CJ, Erickson JC, Kelly EJ, Froelick GJ, Zambrowicz BP, Brinster RL, Palmiter RD (1994) Metallothionein III is expressed in neurons that sequester zinc in synaptic vesicles. J Neurosci $14: 5844-5857$.

O'Halloran TV (1993) Transition metals in control of gene expression. Science 261:715-725.

Palmiter RD, Cole TB, Quaife CJ, Findley SD (1996) ZnT-3, a putative transporter of zinc into synaptic vesicles. Proc Natl Acad Sci USA 93:14934-14939.

Pellegrini-Giampietro DE, Zukin RS, Bennett MV, Cho S, Pulsinelli WA (1992) Switch in glutamate receptor subunit gene expression in CA1 subfield of hippocampus following global ischemia in rats. Proc Natl Acad Sci USA 89:10499-10503.

Perez-Clausell J, Danscher G (1985) Intravesicular localization of zinc in rat telencephalic boutons: a histochemical study. Brain Res 337:91-98.

Peters S, Koh J, Choi DW (1987) Zinc selectively blocks the action of $N$-methyl-D-aspartate on cortical neurons. Science 236:589-593.

Petrozzino JJ, Pozzo Miller LD, Connor JA (1995) Micromolar $\mathrm{Ca}^{2+}$ transients in dendritic spines of hippocampal pyramidal neurons in brain slice. Neuron 14:1223-1231.

Pruss RM, Akeson RL, Racke MM, Wilburn JL (1991) Agonistactivated cobalt uptake identifies divalent cation-permeable kainate receptors on neurons and glial cells. Neuron 7:509-518.

Rose K, Goldberg MP, Choi DW (1993) Cytotoxicity in murine neocortical cell culture. In: Methods in toxicology (Tyson, CA, Frazier JM, eds), pp 46-60. San Diego: Academic.

Sheardown MJ, Suzdak PD, Nordholm L (1993) AMPA, but not NMDA, receptor antagonism is neuroprotective in gerbil global ischaemia, even when delayed 24 hr. Eur J Pharmacol 236:347-353.

Simons TJB (1991) Intracellular free zinc and zinc buffering in human red blood cells. J Membr Biol 123:63-71.

Simons TJB (1993) Measurement of free $\mathrm{Zn}^{2+}$ ion concentration with the fluorescent probe mag-fura-2 (furaptra). J Biochem Biophys Methods 27:25-37.

Sloviter RS (1985) A selective loss of hippocampal mossy fiber Timm stain accompanies granule cell seizure activity induced by perforant path stimulation. Brain Res 330:150-153.

Smart TG, Xie X, Krishek BJ (1994) Modulation of inhibitory and excitatory amino acid receptor ion channels by zinc. Prog Neurobiol 42:393-441.

Tibbits GF, Philipson KD (1985) $\mathrm{Na}^{+}$-dependent alkaline earth metal uptake in cardiac sarcolemmal vesicles. Biochim Biophys Acta 817:327-332.

Tonder N, Johansen FF, Frederickson C J, Zimmer J, Diemer NH (1990) Possible role of zinc in the selective degeneration of dentate hilar neurons after cerebral ischemia in the adult rat. Neurosci Lett 109:247-252. 
Turetsky DM, Canzoniero LMT, Sensi SL, Weiss JH, Goldberg MP, Choi DW (1994) Cortical neurons exhibiting kainate-activated $\mathrm{Co}^{2+}$ uptake are selectively vulnerable to AMPA/kainate receptor-mediated toxicity. Neurobiol Dis 1:101-110.

Vallee BL, Falchuk KH (1993) The biochemical basis of zinc physiology. Physiol Rev 73:79-118.

Vega MT, Villalobos C, Garrido B, Gandia L, Bulbena O, Garcia-Sancho J, Garcia AG, Artalejo AR (1994) Permeation by zinc of bovine chromaffin cell calcium channels: relevance to secretion. Pflügers Arch 429:231-239.

Verdoorn TA, Burnashev N, Monyer H, Seeburg PH, Sakmann B (1991) Structural determinants of ion flow through recombinant glutamate receptor channels. Science 252:1715-1718.

Wang YX, Quastel DM (1990) Multiple actions of zinc on transmitter release at mouse end-plates. Pflügers Arch 415:582-587.

Weiss JH, Hartley DM, Koh JY, Choi DW (1993) AMPA receptor activation potentiates zinc neurotoxicity. Neuron 10:43-49.

Westbrook GL, Mayer ML (1987) Micromolar concentrations of $\mathrm{Zn}^{2+}$ antagonize NMDA and GABA responses of hippocampal neurons. Nature 328:640-643.
Yin HZ, Weiss JH (1995) $\mathrm{Zn}^{2+}$ permeates $\mathrm{Ca}^{2+}$ permeable AMPA/ kainate channels and triggers selective neural injury. NeuroReport 6:2553-2556.

Yin HZ, Turetsky DM, Choi DW, Weiss JH (1994) Cortical neurons with $\mathrm{Ca}^{2+}$ permeable AMPA/kainate channels display distinct receptor immunoreactivity and are GABAergic. Neurobiol Dis 1:43-49.

Yokoyama M, Koh JY, Choi DW (1986) Brief exposure to zinc is toxic to cortical neurons. Neurosci Lett 71:351-355.

Yu SP, Choi DW (1997) $\mathrm{Na}^{+}-\mathrm{Ca}^{2+}$ exchange currents in cortical neurons: concomitant forward and reverse operation and effect of glutamate. Eur J Neurosci 9:1273-1281.

Zalewski PD, Forbes IJ, Betts WH (1993) Correlation of apoptosis with change in intracellular labile $\mathrm{Zn}(\mathrm{II})$ using Zinquin [(2-methyl-8-ptoluesulphonamido-6-quinolyloxy)acetic acid], a new specific fluorescent probe for $\mathrm{Zn}(\mathrm{II})$. Biochem J 296:403-408.

Zalewski PD, Millard SH, Forbes IJ, Kapaniris O, Slavotinek A, Betts WH, Ward AD, Lincoln SF, Mahadevan I (1994) Video image analysis of labile zinc in viable pancreatic islet cells using a specific fluorescent probe for zinc. J Histochem Cytochem 42:877-884. 